\title{
Review
}

\section{XR (Extended Reality: Virtual Reality, Augmented Reality, Mixed Reality) Technology in Spine Medicine: Status Quo and Quo Vadis}

\author{
Tadatsugu Morimoto ${ }^{1, *}\left(\mathbb{D}\right.$, Takaomi Kobayashi ${ }^{1}$, Hirohito Hirata ${ }^{1}\left[\right.$, Koji Otani ${ }^{2}$, Maki Sugimoto ${ }^{3}$, \\ Masatsugu Tsukamoto ${ }^{1} \mathbb{D}$, Tomohito Yoshihara ${ }^{1}$, Masaya Ueno ${ }^{1}$ and Masaaki Mawatari ${ }^{1}$ \\ 1 Department of Orthopaedic Surgery, Faculty of Medicine, Saga University, 5-1-1 Nabeshima, \\ Saga 849-8501, Japan; takaomi_920@yahoo.co.jp (T.K.); h.hirata.saga@gmail.com (H.H.); \\ masa2goo99@yahoo.co.jp (M.T.); tomohito4113@yahoo.co.jp (T.Y.); f8286@cc.saga-u.ac.jp (M.U.); \\ mawatam@cc.saga-u.ac.jp (M.M.) \\ 2 Department of Orthopaedic Surgery, School of Medicine, Fukushima Medical University, \\ Fukushima 960-1295, Japan; kojiotani1964@gmail.com \\ 3 Innovation Lab, Teikyo University Okinaga Research Institute, Tokyo 173-8605, Japan; \\ sgmt@med.teikyo-u.ac.jp \\ * Correspondence: morimot3@cc.saga-u.ac.jp; Tel.: +81-952342343
}

\section{check for} updates

Citation: Morimoto, T.; Kobayashi, T.; Hirata, H.; Otani, K.; Sugimoto, M.; Tsukamoto, M.; Yoshihara, T.; Ueno, M.; Mawatari, M. XR (Extended Reality: Virtual Reality, Augmented Reality, Mixed Reality) Technology in Spine Medicine: Status Quo and Quo Vadis. J. Clin. Med. 2022, 11, 470. https://doi.org/10.3390/ jcm11020470

Academic Editor: Robert C. Cantu

Received: 13 December 2021

Accepted: 11 January 2022

Published: 17 January 2022

Publisher's Note: MDPI stays neutral with regard to jurisdictional claims in published maps and institutional affiliations.

Copyright: (c) 2022 by the authors Licensee MDPI, Basel, Switzerland. This article is an open access article distributed under the terms and conditions of the Creative Commons Attribution (CC BY) license (https:// creativecommons.org/licenses/by/ $4.0 /)$.

\begin{abstract}
In recent years, with the rapid advancement and consumerization of virtual reality, augmented reality, mixed reality, and extended reality (XR) technology, the use of XR technology in spine medicine has also become increasingly popular. The rising use of XR technology in spine medicine has also been accelerated by the recent wave of digital transformation (i.e., case-specific three-dimensional medical images and holograms, wearable sensors, video cameras, fifth generation, artificial intelligence, and head-mounted displays), and further accelerated by the COVID-19 pandemic and the increase in minimally invasive spine surgery. The COVID-19 pandemic has a negative impact on society, but positive impacts can also be expected, including the continued spread and adoption of telemedicine services (i.e., tele-education, tele-surgery, tele-rehabilitation) that promote digital transformation. The purpose of this narrative review is to describe the accelerators of XR (VR, $\mathrm{AR}, \mathrm{MR}$ ) technology in spine medicine and then to provide a comprehensive review of the use of XR technology in spine medicine, including surgery, consultation, education, and rehabilitation, as well as to identify its limitations and future perspectives (status quo and quo vadis).
\end{abstract}

Keywords: augmented reality; extended reality; mixed reality; navigation; spine surgery; virtual reality; telemedicine

\section{Introduction}

Advances in computing power have led to a significant advancement of virtual reality (VR), augmented reality (AR), and mixed reality (MR) technologies. Recently, the term XR (extended reality) technology, which more broadly integrates VR/AR/MR technologies, has been the focus of much attention. VR is "an immersive, completely artificial computersimulated image and environment with real-time interaction" [1]. It is widely used to reproduce the human body structure, pathophysiology, and clinical scenes with a sense of realism. VR in spine medicine has been used most often for medical education, surgical simulation and planning, and intraoperative guidance [2,3]. AR has been described as "the concept of digitally superimposing virtual objects onto physical objects in real space so that individuals can interact with both at the same time" [4]. In practice, computer-generated images are overlaid on real-world images and displayed on video projectors, computers, or tablets. MR, a hybrid of AR and VR, is the result of blending the physical world with the digital world $[5,6]$ and has recently garnered attention, mitigating the limitations of 
VR's exclusion of the real-world environment and AR's inability to interact with threedimensional (3D) data packets [7]. VR and MR have primarily been applied in teaching and preparatory roles, while AR is mainly applied in hands-on surgical settings. The use of MR in spine medicine allows the surgeon to access intraoperative information about the patient's anatomy and superimpose virtual holographic elements on the superficial anatomy of the actual patient in real-time on the operating table, enabling holographicbased navigation $[8,9]$. $X R$ is a general term encompassing VR, $A R$, and MR. XR refers to all real-and-virtual combined environments between human and computer-generated input processed to create an interactive environment. This review covers VR, AR and MR, but for the sake of clarity, they are all referred to as XR.

In recent years, with rapid advancement and consumerization of $X R$ technology, the use of XR technology in spine surgery has also become increasingly popular. The rising use of XR technology in spine medicine can also be attributed to the recent wave of digital transformation, which was further accelerated by the COVID-19 pandemic and the increase in minimally invasive spine surgery (MISS), which we will discuss in detail in Section 2. Digital transformation involves several interesting technologies or devices, which are described in Section 3. According to a review of 8399 articles on VR and AR research published in the medical field from 1992 to 2020, which were analyzed using bibliometric methods, the most popular research topics were diagnostic procedures, surgical procedures, and rehabilitation [10]. In addition, numerous reports have shown the usefulness of XR technology in medical education [10-13]. Therefore, in Section 4, we will discuss the following four major areas of spine medicine in which the application of XR technology has been accelerating: education, medical examination, surgery, and rehabilitation.

Figure 1 illustrates the structure of the above relationship.

\section{Accelerators for the introduction of XR technology in spine medicine}

Digital transformation in spine medicine(2.1)

- Collection(2.1.1)

- Communication (2.1.2)

- Editing (2.1.3)

- Viewing (2.1.4)

The COVID-19 pandemic(2.2)

Minimally invasive spine surgery(2.3)
: CT, MRI, ultrasound scan , Wearable sensor(3.2), Video camera (3.3)

: High performance information communication technologies

$\mathrm{Al}(\mathrm{ML}, \mathrm{DL}), 3 \mathrm{D}$ medical images and holograms (3.1)

$4 \mathrm{~K}, 8 \mathrm{~K}, \mathrm{HMD}(3.4)$, Smart glass

\section{Four major research areas using XR technology in spine medicine}

\section{Education(4.1)}

Medical examination(4.2)

$$
\text { Surgery(4.3) }
$$

Rehabilitation(4.4)
- The Effectiveness of Using 3D Holograms to Teach Anatomy to Medical Students and Residents(4.1.1)

- Tele-education with XR HMD(4.1.2)

- Surgical simulation(4.3.1)/Surgical navigation(4.3.2)

Figure 1. XR technology in spine medicine in contents of this manuscript. XR, extended reality; AI, artificial intelligence; ML, machine learning; DL, deep learning; HMD, head mounted display.

Lastly, in Section 5, limitations, future directions, and possibilities will be discussed.

Given these facts and trends, it is time to discuss how such recent advances will coverage technological and medical insights. In this study, we adopted the narrative review method, which allows us to organize and analyze the existing literature in the field 
of XR technology in spine medicine more extensively, flexibly, and comprehensively in comparison to a systematic review. To that end, many pivotal articles in peer-reviewed scientific journals were selected, which helped to identify key XR technologies in spine medicine. The purpose of this narrative review is to identify the accelerators of XR (VR, $A R, M R)$ technology in spine medicine and then to perform a comprehensive review of the use of XR technology in spine medicine, including surgery, consultation, education, and rehabilitation, as well as to identify its limitations and future perspectives (status quo and quo vadis).

\section{What Has Accelerated the Introduction of XR Technology in Spine Medicine?}

The introduction of XR technology in spine medicine has been accelerated by the recent wave of digital transformation and further accelerated by the COVID-19 pandemic, and the increase in minimally invasive spine surgery.

\subsection{Digital Transformation in Spine Medicine}

Technological advancement in recent years has brought intelligent computing to nearly every industry. The digital transformation wave has also arrived in spine medicine [14,15], largely due to the development of the four digital platforms for handling high-performance big data: collection, communication, editing, and viewing. For example, especially in telemedicine, the combination of high-performance information (i.e., high-resolution CT, wearable sensors, $360^{\circ}$ operative camera), high-performance information communication technologies, high-performance edited images (i.e., 3D medical images or holograms) created using artificial intelligence (AI), and high-performance viewing using a head-mounted display (HMD) has been useful for diagnostics and treatment decisions [16,17]. Thus, advancement in digital transformation combined with the development of intelligence technology for handling high-performance information collection, communication, editing, and viewing has further expanded the application of XR technology in spine medicine.

\subsubsection{Collection}

The collection of high-performance information in medicine can be attributed to the following: (1) advances in image quality and digitization of CT, MRI, and ultrasound scans; (2) development of wearable sensors; (3) development of inexpensive, compact, portable, and high-performance video cameras; and (4) development of surface topography methods in pediatric scoliosis. Wearable sensors (i.e., smartphones) can be used to collect many kinds of data remotely $[18,19]$. Notably, action cameras or $360^{\circ}$ video cameras, which providing an immersive and realistic experience, have been widely used in most areas of surgery and in various clinical education settings [20-22]. The use of surface topography in pediatric scoliosis has been welcomed for its accuracy and reduced radiation exposure [23].

\subsubsection{Communication}

Communication technologies with high performance information, including fifth generation wireless system (5G) and wireless fidelity (Wi-Fi), have the advantages of high data rates and low latency. These are the basis for XR technologies, including other emerging technologies, such as the Internet of wearable sensors, big data, 3D medical images and holograms, cloud computing, and AI, which can combine organically with 5G [16,24]. Furthermore, 5G network-based telerobotic spine surgery has been performed due to the aforementioned digital transformation and progress in robot-assisted spine surgery [25].

\subsubsection{Editing}

The use of $\mathrm{AI}$ in the editing of high-performance information is already essential for image reconstruction. Clinicians have widely used 3D medical images edited by AI and high-performance communication technology. These images vividly reproduce the human body structure, pathophysiology, and clinical scenes with a sense of realism. This informa- 
tion could support medical treatment, including navigation surgery, education of medical students and residents, patient explanation, rehabilitation, and telemedicine [26,27]. Threedimensional medical images and holograms are more practical than conventional models such as a 3D-printed models, as they allow clinicians to move objects around or remove certain areas. They can also be easily obtained by inputting high-performance information.

\subsubsection{Viewing}

The most common way to view 3D medical images edited with the above-mentioned high-performance information is with a high-resolution display, which can take the form of either a traditional monitor or a head-mounted display (HMD) [28-30]. When combined with a $4 \mathrm{~K}$ or $8 \mathrm{~K}$ ultra-high-definition monitor system, it can provide sharper and clearer streaming video, providing detailed content that resolves information beyond the retina and helps to make a visual diagnosis [16]. Recent improvements in the medical image analysis and visualization equipment have led to the use of 3D medical images and holograms in clinical practice [5]. With the evolution of HMD, XR technology has been integrated into HMD systems. Three-dimensional holograms can be displayed on HMD; VR with HMD has been used to educate and guide trainees in pedicle screw fixation and has shown greater accuracy in comparison to traditional teaching methods [31,32]. AR with HMD has been primarily used to facilitate intraoperative navigation/guidance in MISS [33,34]. With the introduction of $\mathrm{AR} / \mathrm{MR}$ with $\mathrm{HMD}$, an omnidirectional hologram is projected onto the surgeon's field of view, allowing the surgeon to concentrate on the surgical field without returning to the monitor [7].

\subsection{The COVID-19 Pandemic}

The social-distancing guidelines in response to the COVID-19 pandemic have accelerated digital transformation, creating a context that will continue to drive innovation and technological adoption. Similarly, the COVID-19 pandemic has brought about significant changes in medical education for residents and students around the world, disruptions to medical education, a reduction in elective operations, and restrictions on physical participation in workshops or conferences [35]. Thus, the use of technology to maintain medical treatment and education has become more rapid and innovative than ever before. As a result, many healthcare organizations have been increasingly interested in XR technology: patient care and management, the education of residents and medical students (i.e., online lectures, remote access to teaching ward rounds by XR technology [36], preoperative planning and simulation, and remote rehabilitation (telerehabilitation) [17,36,37].

With the continuous development and advancement of the abovementioned digital transformation, tele-medicine has become an essential part of medical information technology construction. In addition to isolation from social contact and interaction by stay-at-home policies, medical students have suffered from depression [38]. Therefore, telemedicine may be important not only for patients but also for medical students. Until vaccines are available or herd immunity is achieved, a repeat of the COVID-19 pandemic is expected, and no significant reversal of the digital trends is expected in the post-pandemic environment. Thus, we need to continue to pay attention to XR technology.

\subsection{Minimally Invasive Spine Surgery (MISS)}

Over the past 20 years, there has been an explosion of new MISS methods, which often require new skills and tools [7,39]. Advances in XR technology have facilitated the development of new skills and tools in spine surgery. MISS has become a common technique, bringing many benefits to both surgeons and patients; however, these techniques rely heavily on indirect visualization and/or navigation guidance [40-42]. XR technology, which can visualize the anatomy and guide the surgeon as precisely as intraoperative navigation, has been implemented in the MISS field. On the other hand, the narrow surgical field in MISS and the difficulty in obtaining accurate spatial awareness during surgery are factors that hinder the education and acquisition of surgical skills. In addition, 
MISS surgery is associated with a high rate of radiation exposure because surgeons must rely on X-ray images to confirm the instrumentation accuracy $[43,44]$.

It has been reported that the usefulness of XR technology in spine surgery includes high-precision surgery, reduced radiation, and a shortened surgical time.

Therefore, in MISS, XR technology has played an increasingly important role in education and treatment [39].

\section{Technologies Supporting the Digital Transformation of Spine Medicine}

As discussed in Section 2, many XR technologies and devices have supported digital transformation in spine medicine. The following is a supplementary description of some particularly interesting technologies and devices.

\subsection{D Medical Images and Holograms}

The areas of application of 3D medical images and holograms are diverse and promising. They include education, patient follow-up and informed consent, and surgical simulation/navigation.

\subsubsection{Image Capture in Medical Application Systems Using XR Technology}

Conventional two-dimensional imaging modalities mainly include X-rays, $\mathrm{CT}$, and MRI, which often require years of clinical experience and a high degree of spatial imagination for an accurate diagnosis. For medical students and residents, the lack of an accurate understanding of the three-dimensional positioning of the organs makes it difficult to assess preoperative images and understand surgical techniques. Case-specific 3D holograms can be used as a new educational tool to improve the competency of medical students and residents [44], and as a tool for patient education [45]. Since XR technology is computer-based, it can perform learning activities that would be impossible in the real world. For example, students can already use Anatomage TABLE ${ }^{\mathrm{TM}}$ to observe 3D dissection to the center of a cell in VR. In this way, software development can provide an engaging learning experience that allows for a deeper understanding of complex concepts [46].

Surgeons frequently require the real-time estimation of 3D data from 2D images, and the application of XR technology in spine surgery could facilitate this task, improving patient safety and surgical efficiency. Medical images in spine surgery-even 3Dreconstructed images - can only be viewed on a flat monitor, which can lead to inaccurate spatial perception. Therefore, the intraoperative use of $3 \mathrm{D}$ holograms with high spatial awareness is desirable, which can enhance the safety of the operation (Figure 2A). Furthermore, 3D holograms can be viewed and moved through easy gesture-handling, without monitors in any place, including the operative room. Elements such as the integration of touchless features provide the setting of a sterile environment (Figure 2B).
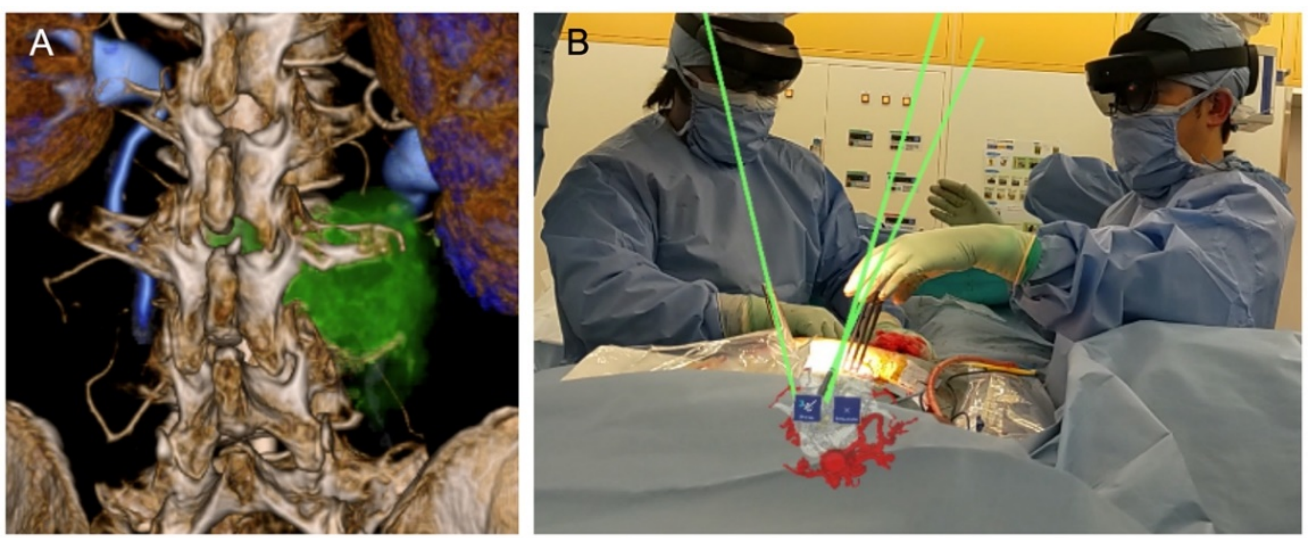

Figure 2. Three-dimensional medical images and holograms for preoperative simulation (A) and intraoperative surgical assistant (B). The green line was used as a guideline for the insertion of pedicle screws. 


\subsubsection{D-Based Classification Analysis}

For some diseases where an understanding of the 3D anatomy is important (i.e., scoliosis), 3D-based classification using AI has been reported [47,48]. The use of such 3D-based classification systems for scoliosis may provide more insight into pathology than conventional two-dimensional (2D)-based classification systems. While the clinical relevance and practical usefulness of the $2 \mathrm{D}$ perspective has been considered, the $3 \mathrm{D}$ perspective will give us a more solid understanding of the relevance, prognosis, or targeted diagnostic evaluation of the spinal structure phenotypes in relation to pain, function, and disability profiles [49]. It may be time to reconsider the $2 \mathrm{D}$ evaluation of what is essentially a 3D structure. Furthermore, with the advancement of XR technology, 3D reconstruction will become easier and quicker. Therefore, 3D-based classification of spinal diseases will become more common in the coming years.

\subsubsection{Surface Topography in Spinal Posture}

Surface topography (e.g., formetric 4D from DIERS Medical Systems (Chicago, IL, USA)), which has a diagnostic accuracy comparable to that of X-ray, is being used increasingly frequently for postural analyses [50].

Particularly for scoliosis screening in children, surface topography is attracting attention because of its low radiation dose.

Screening is accompanied by problems such as the burden on doctors to read the images; however, with the ongoing advancement of AI, these problems will be solved [51].

\subsection{Wearable Sensors}

Smartphones can collect parameters that need to be measured in telemedicine, such as ECG, arrhythmia, falls, step accelerometer data, gyroscope data, temperature, blood saturation, pulse, respiration, sleep quality, falls, and walk assessments [50-54]. Wearable sensors, also known as the Internet of medical things (IoMT), can also be used to collect data in real time to help monitor and manage patients remotely $[18,19]$. Although telemedicine in orthopedics has lagged behind other specialties, such as radiology, cardiology, and psychiatry [55], there have been reports on the use of a combination of wearable sensors and VR for shoulder rehabilitation [56], the postoperative evaluation of lumbar disc herniation, smart shoes for lumbar spinal stenosis [52], and the monitoring of brace usage for scoliosis [57-60]. In terms of spine medicine, information on gait assessment by wearable sensors such as smartphones or smart shoes may be useful for the preoperative assessment of neurological gait disorders and postoperative monitoring of spine surgery [60].

With the COVID-19 pandemic, telemedicine using a combination of VR and wearable sensors has become popular $[59,60]$. Wearable sensors have the advantage of being able to more accurately monitor a patient's gait and posture in "everyday" life, which would not be reflected in controlled tests performed in front of a doctor. Thus, wearable sensors have been widely used in various telemedicine fields, including patient education, medical examination, and rehabilitation. The combination of wearable sensors and telemedicine as an audiovisual communication platform using XR technology will bring many benefits to both healthcare providers and patients, including benefits in relation to cost, time, and healthcare accessibility for patients in remote areas.

\subsection{Action Cameras and $360^{\circ}$ Operative Cameras (Video)}

The ideal camera for recording surgery should be small, lightweight, comfortable, easy to use, able to depict the surgeon's view, provide high-definition images and video, have long battery life, be inexpensive, and allow for easy management of images and video [22] Since such an ideal camera does not currently exist, in many cases, people cope by using different cameras for different purposes, or by using combinations of multiple cameras.

Action cameras that have been applied for surgical recording include the GoPro Hero Series (GoPro, Inc., San Mateo, CA, USA) [61,62] and Google Glass (Google, Inc., Mountain view, CA, USA) [22], which can collect blur-free video images from the surgeon's 
perspective. The GoPro is a small, lightweight, high-resolution action camera that has mainly been used to record action sports, but which has recently been used in clinical education. When worn on a head-mount, it has a 149-degree wide-angle field of view and can capture most of the visual information available to the wearer [60].

Moreover, $360^{\circ}$ operative video has been used not only to analyze surgical performance for medical education but also for orientation in new environments, team training, and formal multi-disciplinary examinations, because it allows users to view images from all angles at the same time, providing an immersive and realistic experience [20].

The high level of sterility required in spinal instrumentation surgery has restricted medical students' access to surgery, and the COVID-19 pandemic has accelerated this trend. Moreover, the increase in the number of MISS procedures makes it more difficult for students to learn surgical techniques. In addition, conventional ceiling-mounted video camera images show medical students the anatomy in the image, but do not allow them to observe how the surgeon manipulates the surgical instruments. With the use of XR technology, high-resolution videos captured with an action camera from the surgeon's point of view and $360^{\circ}$ operative video have become more realistic and immersive through online live broadcasts of surgery, which may solve the abovementioned problems for medical students.

\subsection{XR (VR/MR)-HMD}

A series of recent studies have indicated that $X R$ technology provides the opportunity to co-create experiences such as HMDs and goggle types of devices that can already produce high-quality graphics and experiences.

\subsubsection{Viewing via HMD}

Three-dimensional holograms created before surgery are projected onto a clean surgical field during surgery and can be viewed in three dimensions, which improves spatial awareness and allows the images to be shared among the doctors involved in the operation $[8,9]$. There are two types of MR glasses on the market: HoloLens (Microsoft, Inc., Redmond, WA, USA) and Magic Leap1 (Magic Leap, Inc., Plantation, FL, USA) [7,63-66].

In recent years, compact, lightweight, and comfortable HMDs have become commercially available. These smart glasses can superimpose computer images translucently on images through the lens, allowing the surgeon to obtain anatomical and navigation information without narrowing their field of view. Furthermore, it will enable surgeons to proceed with surgery without taking their attention away from the procedure, resulting in shorter operative times and reduced radiation exposure [67-69]. In the field of neurospine surgery, several attempts to use smart-glass displays as intraoperative neuromonitors [70], endoscopic monitors [71], display devices for fluoroscopy [68], and 3D navigation screens $[67,69]$ have been reported. Moreover, with VR-HMD as a video viewing device, the $360^{\circ}$ operative images and surgeon view with action camera can provide residents and medical students with a sense of immersion and realism, allowing them to experience surgery in an educational way, rather than by just observing it [20,22].

\subsubsection{Recording via HMD}

Some HMDs have camera and video recording capabilities, which may be a more useful adjunct to surgical education, information sharing, real-time consultation, and remote teaching and monitoring [28-30,72,73]. Surgical techniques have been passed down from generation to generation as tacit knowledge. Since it is difficult to quantify them, it is impossible to evaluate their quality, and it takes time to learn them. Operative videos from the surgeon's perspective using HMDs, especially from experienced doctors, signify the digitalization of surgical techniques into digital content. Digitized surgical videos can be viewed anytime and anywhere with highly immersive and realistic VR-HMDs, enabling surgeons to provide highly accurate feedback, and medical students and residents to pass on tacit knowledge specific to surgery by reliving the surgery [39]. 


\subsubsection{VR-HMD as a Sensor}

A cervical range of motion assessment is useful for preoperative and postoperative evaluation of the cervical spine, and for checking the effect of rehabilitation. VR systems have been shown to be convenient, non-invasive, harmless to the human body, and capable of assessing the cervical range of motion with a high degree of accuracy [72,73]. It could also be used to examine the relationship between data measured by VR equipment and clinical imaging data, and for follow-up applications in remote areas [72].

\section{XR Technology in Spine Medicine: Education, Medical Examination, Surgery, and Rehabilitation}

The four major fields of spine medicine where the application of XR technology has been accelerated are education, consultation, surgery, and rehabilitation.

\subsection{Education}

4.1.1. The Effectiveness of Using 3D Holograms to Teach Anatomy to Medical Students and Residents

The dissection of cadavers is important in medical education, but there are ethical issues involved in using cadavers, as well as issues of time, cost, and availability of donated bodies for training. Thus, dissection using XR technology has been attracting attention.

Chytas et al. [74] provide an overview of the implementation of XR technology in anatomy education and recommend educators to incorporate $\mathrm{XR}$ technology, such as exposing details of human anatomy and surgical procedures in a VR environment and using AR. Naturally, 3D holograms help to improve the intuitive understanding and spatial awareness through stereoscopic vision [75]. Thus, 3D holograms edited with XR technology can effectively improve the quality of teaching, stimulate students' interest in learning, and improve students' understanding of anatomical knowledge. Beyond the improvement of anatomical knowledge, other advantages of XR technology that use 3D holograms for medical student anatomy education include $24 \mathrm{~h}$ free access and gamified elements, which contribute to increased satisfaction. The use of XR technology in anatomy education has been used in relation to internal human anatomy, the anatomy of the ear, nose, and temporal bone, surgery, neuroanatomy, and cardiac anatomy [10]. Thus far, there are no reports in the area of spine medicine.

In the context of spine surgery education and training, the use of XR technology, including 3D holograms for preoperative planning, and intraoperative visualization may promote a faster understanding of surgical anatomy and skills, accelerate the learning curve, contribute to accurate and safe surgery, and increase patients' satisfaction $[2,7,75-78]$.

\subsubsection{Tele-Education with XR HMD}

Tele-education may also be beginning to gain prominence due to the COVID-19 pandemic. In medical education, HMD can provide distance-learning students with an immersive and involved experience that was not previously possible. Conversely, when teachers wore HMD (HoloLens 2) to educate medical students at a London teaching hospital and conducted educational ward rounds via remote access, the results were effective and highly satisfactory [36].

Mcknight et al. [39] reported that remote surgical guidance from an experienced surgeon using an iPad or Google Glass HMD as a display benefits trainees as well as experienced surgeons learning a new skill, such as shoulder arthroscopy or shoulder arthroplasty [79-81]. Thus far, there are no reports of tele-education in spine medicine, so this is a future issue.

\subsection{Medical Examination}

Telemedicine involves XR technology, including wearable sensors and high-performance video cameras, to allow healthcare providers to evaluate, diagnose, monitor, treat, and educate patients "virtually" by allowing remote information visualization $[16,18,19,57,58,82,83]$. 
Remote $\mathrm{XR}(\mathrm{VR})$-based observation has been reported to be accurate, convenient, noninvasive, and time and specimen saving [84].

In telemedicine, the combination of wearable sensors, high-performance video, and HMD can be useful as diagnostic and follow-up support tools. Haddas et al. [82] reported that cameras and gait analysis platforms have described patterns of gait dysfunction caused by conditions such as myelopathy. In addition, patients who receive telemedicine for spine-related complaints have given high ratings for overall satisfaction and ease of use [85].

Although telemedicine spread rapidly during the COVID-19 pandemic, it has not yet been determined how best to perform an objective physical examination of the spine in the remote setting [85]. The limitations of telemedicine in performing a physical examination or collecting proper manual neurological findings in the field of spine medicine have been the biggest obstacle to adoption by spinal surgeons [85]. Guidelines have been developed for the implementation of virtual physical examinations, including specific testing methods for spine surgeons to assess the physical function, motor strength, and sensation $[17,86-88]$; however, these are still insufficient. In the future, research is needed to standardize remote control and improve the accuracy of remote diagnoses.

\subsection{Surgery}

There are increasing reports of hologram-based navigation surgery, which aims to improve existing surgical navigation by recreating the patient's anatomy in 3D and superimposing it on the surgeon's field of view (Figure 2). The development of XR technology with HMD [89] has contributed to hologram-based navigation. Moreover, Terander et al. [90] developed augmented reality surgical navigation (ARSN) for pedicle screw placement in the hybrid XR operating room. HMD visualization has solved the problem of the risk of attention shift, where the surgeon looks away from the surgical field to observe the monitor.

There have been numerous reports on proof of concept and surgical simulation with cadaveric, phantom, and animal models using XR technology: pedicle screw insertion (cervical [91], thoracic [92,93], thoracolumbar [94,95], lumbar [31,63,64,93,96-101]), cervical lateral mass screw insertion [32], vertebral body puncture [102-104], vertebroplasty (kyphoplasty) [105-109], percutaneous sacroiliac screw insertion [110-112], percutaneous lumbar discectomy [105,113-115], and facet joint injection [116-118]. However, few studies have evaluated the application of XR technology in clinical practice for pedicle screw placement [90,119], targeted cervical foraminotomy [120], osteotomy planning [121] and percutaneous intervention [122-124], or extradural and intradural tumor resection [125,126].

\subsubsection{Surgical Simulation}

A summary of surgical simulation using hologram with XR technology in spine surgery is shown in Table 1.

Table 1. A summary of surgical simulation with $\mathrm{XR}$ technology in spine surgery.

\begin{tabular}{|c|c|c|c|c|c|c|c|}
\hline Study & Country & Procedure & VR/AR & Model & Simulator & Participant & Outcome \\
\hline $\begin{array}{l}\text { Hou et al., } \\
2018 \text { [91] }\end{array}$ & China & $\begin{array}{c}\text { Cervical } \\
\text { pedicle screw }\end{array}$ & $\begin{array}{c}\text { VR- } \\
\text { simulation }\end{array}$ & $\begin{array}{c}\text { Phantom } \\
\text { model, } \\
\text { Cadaver } \\
\text { model }\end{array}$ & $\begin{array}{c}\text { Virtual Surgery } \\
\text { Training System } \\
\text { (VSTS) }\end{array}$ & Residents & Accuracy \\
\hline $\begin{array}{l}\text { Hou et al., } \\
2018 \text { [92] }\end{array}$ & China & $\begin{array}{c}\text { Thoracic } \\
\text { pedicle screw }\end{array}$ & $\begin{array}{c}\text { VR- } \\
\text { simulation }\end{array}$ & $\begin{array}{c}\text { Phantom } \\
\text { model, } \\
\text { Cadaver } \\
\text { model }\end{array}$ & $\begin{array}{c}\text { Virtual Surgery } \\
\text { Training System } \\
\text { (VSTS) }\end{array}$ & Residents & Accuracy \\
\hline $\begin{array}{l}\text { Luciano } \\
\text { et al., 2011 } \\
\text { [93] }\end{array}$ & USA & $\begin{array}{c}\text { Thoracic } \\
\text { pedicle screw }\end{array}$ & AR-guide & $\begin{array}{c}\text { Phantom } \\
\text { model }\end{array}$ & $\begin{array}{c}\text { ImmersiveTouch } \\
\text { (San Francisco, } \\
\text { CA, USA) }\end{array}$ & Residents & Accuracy \\
\hline
\end{tabular}


Table 1. Cont.

\begin{tabular}{|c|c|c|c|c|c|c|c|}
\hline Study & Country & Procedure & VR/AR & Model & Simulator & Participant & Outcome \\
\hline $\begin{array}{l}\text { Xiang et al., } \\
2015 \text { [94] }\end{array}$ & China & $\begin{array}{l}\text { Thoracolumbar } \\
\text { pedicle screw }\end{array}$ & $\begin{array}{c}\text { VR- } \\
\text { simulation }\end{array}$ & $\begin{array}{l}\text { Phantom } \\
\text { model }\end{array}$ & $\begin{array}{l}\text { Proprietary } \\
\text { cross-platform } \\
\text { simulator } \\
\text { written in C++ }\end{array}$ & Residents & Time \\
\hline $\begin{array}{l}\text { Xin et al., } \\
2018 \text { [95] }\end{array}$ & China & $\begin{array}{l}\text { Thoracolumbar } \\
\text { pedicle screw }\end{array}$ & $\begin{array}{c}\text { VR- } \\
\text { simulation }\end{array}$ & $\begin{array}{c}\text { Phantom } \\
\text { model, } \\
\text { Cadaver } \\
\text { model }\end{array}$ & $\begin{array}{c}\text { Unspecified VR } \\
\text { system, UG } \\
\text { NX8.0, Seimens, } \\
\text { Munich, } \\
\text { Germany }\end{array}$ & Trainees & Time \\
\hline $\begin{array}{c}\text { Chitale } \\
\text { et al., 2013 } \\
{[96]}\end{array}$ & USA & $\begin{array}{c}\text { Lumbar } \\
\text { pedicle screw }\end{array}$ & AR-guide & $\begin{array}{l}\text { Phantom } \\
\text { model }\end{array}$ & $\begin{array}{c}\text { Medtronic } \\
\text { Surgical } \\
\text { Technologies }\end{array}$ & Residents & $\begin{array}{l}\text { Accuracy, } \\
\text { Time }\end{array}$ \\
\hline $\begin{array}{l}\text { Gasco et al., } \\
2014 \text { [31] }\end{array}$ & USA & $\begin{array}{c}\text { Lumbar } \\
\text { pedicle screw }\end{array}$ & AR-guide & $\begin{array}{l}\text { Cadaver } \\
\text { model }\end{array}$ & $\begin{array}{c}\text { ImmersiveTouch } \\
\text { (San Francisco, } \\
\text { CA, USA }\end{array}$ & $\begin{array}{l}\text { Medical } \\
\text { students }\end{array}$ & Accuracy \\
\hline $\begin{array}{l}\text { Gibby et al., } \\
2019 \text { [63] }\end{array}$ & USA & $\begin{array}{c}\text { Lumbar } \\
\text { pedicle screw }\end{array}$ & AR-guide & $\begin{array}{l}\text { Phantom } \\
\text { model }\end{array}$ & $\begin{array}{c}\text { Microsoft } \\
\text { HoloLens } \\
\text { (Redmond, WA, } \\
\text { USA), Novarad } \\
\text { OpenSight } \\
\text { (American Fork, } \\
\text { UT, USA }\end{array}$ & $\begin{array}{l}\text { Medical } \\
\text { students, } \\
\text { Trainees }\end{array}$ & $\begin{array}{l}\text { Accuracy, } \\
\text { Time }\end{array}$ \\
\hline $\begin{array}{l}\text { Liebmann } \\
\text { et al., } 2019 \\
{[64]}\end{array}$ & Switzerland & $\begin{array}{c}\text { Lumbar } \\
\text { pedicle screw }\end{array}$ & AR-guide & $\begin{array}{l}\text { Phantom } \\
\text { model }\end{array}$ & $\begin{array}{c}\text { Microsoft } \\
\text { HoloLens } \\
\text { (Redmond, WA, } \\
\text { USA) }\end{array}$ & Surgeon & Accuracy \\
\hline $\begin{array}{l}\text { Luciano } \\
\text { et al., 2011 } \\
{[93]}\end{array}$ & USA & $\begin{array}{c}\text { Lumbar } \\
\text { pedicle screw }\end{array}$ & AR-guide & $\begin{array}{l}\text { Phantom } \\
\text { model }\end{array}$ & $\begin{array}{c}\text { ImmersiveTouch } \\
\text { (San Francisco, } \\
\text { CA, USA) }\end{array}$ & $\begin{array}{l}\text { Trainees, } \\
\text { Residents }\end{array}$ & Accuracy \\
\hline $\begin{array}{l}\text { Ma et al., } \\
2017 \text { [97] }\end{array}$ & China & $\begin{array}{c}\text { Lumbar } \\
\text { pedicle screw }\end{array}$ & AR-guide & $\begin{array}{l}\text { Phantom } \\
\text { model }\end{array}$ & $\begin{array}{l}\text { Unspecified } \\
\text { developed } \\
\text { surgical } \\
\text { navigation } \\
\text { system }\end{array}$ & Surgeon & Accuracy \\
\hline $\begin{array}{c}\text { Molina } \\
\text { et al., 2019 } \\
{[98]}\end{array}$ & USA & $\begin{array}{c}\text { Lumbar } \\
\text { pedicle screw }\end{array}$ & AR-guide & $\begin{array}{l}\text { Cadaver } \\
\text { model }\end{array}$ & $\begin{array}{l}\text { Unspecified } \\
\text { developed } \\
\text { surgical } \\
\text { navigation } \\
\text { system (AR) }\end{array}$ & 2 Surgeons & $\begin{array}{l}\text { Accuracy, } \\
\text { Question- } \\
\text { naire }\end{array}$ \\
\hline $\begin{array}{c}\text { Molina } \\
\text { et al., 2020 } \\
\text { [99] }\end{array}$ & USA & $\begin{array}{c}\text { Lumbar } \\
\text { pedicle screw }\end{array}$ & AR-guide & $\begin{array}{c}\text { Cadaver } \\
\text { model }\end{array}$ & $\begin{array}{l}\text { Unspecified } \\
\text { developed } \\
\text { surgical } \\
\text { navigation } \\
\text { system (AR) }\end{array}$ & 2 Surgeons & Accuracy \\
\hline $\begin{array}{l}\text { Mostafa } \\
\text { et al., 2017 } \\
{[100]}\end{array}$ & Canada & $\begin{array}{c}\text { Lumbar } \\
\text { pedicle screw }\end{array}$ & $\begin{array}{c}\text { VR- } \\
\text { simulation }\end{array}$ & $\begin{array}{l}\text { Phantom } \\
\text { model }\end{array}$ & $\begin{array}{c}\text { NeurosimVR, } \\
\text { ImmersiveTouch } \\
\text { (San Francisco, } \\
\text { CA, USA) }\end{array}$ & Surgeons & Questionnaire \\
\hline $\begin{array}{c}\text { Rambani } \\
\text { et al., 2014 } \\
\text { [101] }\end{array}$ & UK & $\begin{array}{c}\text { Lumbar } \\
\text { pedicle screw }\end{array}$ & $\begin{array}{c}\text { VR- } \\
\text { simulation }\end{array}$ & $\begin{array}{l}\text { Phantom } \\
\text { model }\end{array}$ & $\begin{array}{l}\text { Unspecified } \\
\text { developed } \\
\text { computer- } \\
\text { assisted } \\
\text { orthopedic } \\
\text { training system }\end{array}$ & Trainees & $\begin{array}{l}\text { Accuracy, } \\
\text { Time, } \\
\text { Radiation } \\
\text { exposure }\end{array}$ \\
\hline
\end{tabular}


Table 1. Cont.

\begin{tabular}{|c|c|c|c|c|c|c|c|}
\hline Study & Country & Procedure & VR/AR & Model & Simulator & Participant & Outcome \\
\hline $\begin{array}{l}\text { Gottschalk } \\
\text { et al., 2015 } \\
\text { [32] }\end{array}$ & USA & $\begin{array}{l}\text { Cervical lateral } \\
\text { mass screw }\end{array}$ & AR-guide & $\begin{array}{l}\text { Cadaver } \\
\text { model, } \\
\text { Sawbone } \\
\text { model }\end{array}$ & $\begin{array}{l}\text { Stealth 3D } \\
\text { Navigation Unit, } \\
\text { Medtronic, } \\
\text { Minneapolis, } \\
\text { MN, USA }\end{array}$ & Residents & Accuracy \\
\hline $\begin{array}{l}\text { Fritz et al., } \\
2013 \text { [102] }\end{array}$ & USA & $\begin{array}{l}\text { Lumbar } \\
\text { vertebral body } \\
\text { puncture }\end{array}$ & AR-guide & $\begin{array}{l}\text { Cadaver } \\
\text { model }\end{array}$ & $\begin{array}{l}\text { Unspecified } \\
\text { developed } \\
\text { magnetic } \\
\text { resonance } \\
\text { (MR)-guided } \\
\text { osseous biopsy }\end{array}$ & Radiologist & $\begin{array}{l}\text { Accuracy, } \\
\text { Time }\end{array}$ \\
\hline $\begin{array}{l}\text { U-Thainual } \\
\text { et al., } 2013 \\
\text { [103] }\end{array}$ & Canada & $\begin{array}{l}\text { Lumbar } \\
\text { vertebral body } \\
\text { puncture }\end{array}$ & AR-guide & $\begin{array}{l}\text { Phantom } \\
\text { model }\end{array}$ & $\begin{array}{c}\text { Unspecified } \\
\text { developed } \\
\text { MRI-guided } \\
\text { musculoskeletal } \\
\text { interventions } \\
\text { Magnetic } \\
\text { Resonance Image } \\
\text { Overlay System } \\
\text { (MR-IOS). }\end{array}$ & Operators & $\begin{array}{l}\text { Accuracy, } \\
\text { Time }\end{array}$ \\
\hline $\begin{array}{c}\text { Färber } \\
\text { et al., 2009 } \\
{[104]}\end{array}$ & Germany & $\begin{array}{l}\text { Lumbar } \\
\text { vertebral body } \\
\text { puncture }\end{array}$ & $\begin{array}{c}\text { VR- } \\
\text { simulation }\end{array}$ & $\begin{array}{l}\text { Phantom } \\
\text { model }\end{array}$ & $\begin{array}{c}\text { Sensable } \\
\text { Phantom } \\
\text { Premium } 1.5\end{array}$ & $\begin{array}{l}\text { Medical } \\
\text { students }\end{array}$ & Accuracy \\
\hline $\begin{array}{l}\text { Deib et al., } \\
2018 \text { [105] }\end{array}$ & USA & $\begin{array}{l}\text { Vertebroplasty } \\
\text { (Kyphoplasty) }\end{array}$ & AR-guide & $\begin{array}{l}\text { Phantom } \\
\text { model }\end{array}$ & $\begin{array}{l}\text { Unspecified } \\
\text { developed } \\
\text { system }\end{array}$ & Operators & $\begin{array}{l}\text { Accuracy, } \\
\text { Time }\end{array}$ \\
\hline $\begin{array}{l}\text { Koch et al., } \\
2019 \text { [106] }\end{array}$ & Germany & $\begin{array}{l}\text { Vertebroplasty } \\
\text { (Kyphoplasty) }\end{array}$ & $\begin{array}{c}\text { VR- } \\
\text { simulation }\end{array}$ & $\begin{array}{l}\text { Phantom } \\
\text { model }\end{array}$ & $\begin{array}{c}\text { VR } \\
\text { vertebroplasty } \\
\text { simulator }\end{array}$ & Operators & Questionnaire \\
\hline $\begin{array}{l}\text { Weigl et al., } \\
2016 \text { [107] }\end{array}$ & Germany & $\begin{array}{l}\text { Vertebroplasty } \\
\text { (Kyphoplasty) }\end{array}$ & $\begin{array}{c}\text { VR- } \\
\text { simulation }\end{array}$ & $\begin{array}{l}\text { Phantom } \\
\text { model }\end{array}$ & $\begin{array}{l}\text { Novint Falcon } \\
\text { (Novint } \\
\text { Technologis, Inc., } \\
\text { Albuquerque, } \\
\text { NM, USA) }\end{array}$ & Surgeons & $\begin{array}{c}\text { Radiation } \\
\text { exposure, } \\
\text { Workload } \\
\text { (SURG-TLX } \\
\text { scores } \\
\text { (mental } \\
\text { workload)) }\end{array}$ \\
\hline $\begin{array}{l}\text { Wucherer } \\
\text { et al., } 2014 \\
{[108]}\end{array}$ & Germany & $\begin{array}{l}\text { Vertebroplasty } \\
\text { (Kyphoplasty) }\end{array}$ & $\begin{array}{c}\text { VR- } \\
\text { simulation }\end{array}$ & $\begin{array}{l}\text { Phantom } \\
\text { model }\end{array}$ & $\begin{array}{l}\text { Novint Falcon } \\
\text { (Novint } \\
\text { Technologis, Inc., } \\
\text { Albuquerque, } \\
\text { NM, USA) }\end{array}$ & Surgeons & None \\
\hline $\begin{array}{c}\text { Wucherer } \\
\text { et al., 2015 } \\
\text { [109] }\end{array}$ & Germany & $\begin{array}{l}\text { Vertebroplasty } \\
\text { (Kyphoplasty) }\end{array}$ & $\begin{array}{c}\text { VR- } \\
\text { simulation }\end{array}$ & $\begin{array}{l}\text { Phantom } \\
\text { model }\end{array}$ & $\begin{array}{l}\text { Novint Falcon } \\
\text { (Novint } \\
\text { Technologis, Inc., } \\
\text { Albuquerque, } \\
\text { NM, USA) }\end{array}$ & Surgeons & $\begin{array}{c}\text { Radiation } \\
\text { exposure, } \\
\text { Workload } \\
\text { (SURG-TLX } \\
\text { scores } \\
\text { (mental } \\
\text { workload)) }\end{array}$ \\
\hline $\begin{array}{c}\text { Dennler } \\
\text { et al., } 2021 \\
{[110]}\end{array}$ & Switzerland & $\begin{array}{l}\text { Percutaneous } \\
\text { sacroiliac screw } \\
\text { insertion }\end{array}$ & AR-guide & $\begin{array}{l}\text { Sawbone } \\
\text { model }\end{array}$ & $\begin{array}{l}\text { Unspecified } \\
\text { developed } \\
\text { system }\end{array}$ & Surgeons & Accuracy \\
\hline
\end{tabular}


Table 1. Cont.

\begin{tabular}{|c|c|c|c|c|c|c|c|}
\hline Study & Country & Procedure & VR/AR & Model & Simulator & Participant & Outcome \\
\hline $\begin{array}{l}\text { Jeong et al., } \\
2019 \text { [111] }\end{array}$ & Korea & $\begin{array}{l}\text { Percutaneous } \\
\text { sacroiliac screw } \\
\text { insertion }\end{array}$ & $\begin{array}{c}\text { VR- } \\
\text { simulation }\end{array}$ & $\begin{array}{l}\text { Phantom } \\
\text { model, } \\
\text { Cadaver } \\
\text { model }\end{array}$ & $\begin{array}{l}\text { Unspecified } \\
\text { developed } \\
\text { system }\end{array}$ & Surgeons & Accuracy \\
\hline $\begin{array}{l}\text { Wang et al., } \\
2016 \text { [112] }\end{array}$ & China & $\begin{array}{l}\text { Percutaneous } \\
\text { sacroiliac screw } \\
\text { insertion }\end{array}$ & AR-guide & $\begin{array}{c}\text { Cadaver } \\
\text { model }\end{array}$ & $\begin{array}{l}\text { Unspecified } \\
\text { developed } \\
\text { system }\end{array}$ & Surgeons & Accuracy \\
\hline $\begin{array}{l}\text { Deib et al., } \\
2018 \text { [105] }\end{array}$ & USA & $\begin{array}{c}\text { Lumbar } \\
\text { percutaneous } \\
\text { lumbar } \\
\text { discectomy }\end{array}$ & AR-guide & $\begin{array}{l}\text { Phantom } \\
\text { model }\end{array}$ & $\begin{array}{l}\text { Unspecified } \\
\text { developed } \\
\text { system }\end{array}$ & Operators & $\begin{array}{l}\text { Accuracy, } \\
\text { Time }\end{array}$ \\
\hline $\begin{array}{c}\text { Bisson } \\
\text { et al., 2010 } \\
\text { [113] }\end{array}$ & Canada & $\begin{array}{c}\text { Lumbar } \\
\text { percutaneous } \\
\text { lumbar } \\
\text { discectomy }\end{array}$ & $\begin{array}{c}\text { VR- } \\
\text { simulation }\end{array}$ & $\begin{array}{l}\text { Phantom } \\
\text { model }\end{array}$ & $\begin{array}{l}\text { Unspecified } \\
\text { developed } \\
\text { system }\end{array}$ & Operators & Accuracy \\
\hline $\begin{array}{l}\text { Hu et al., } \\
2017 \text { [114] }\end{array}$ & China & $\begin{array}{c}\text { Lumbar } \\
\text { percutaneous } \\
\text { lumbar } \\
\text { discectomy }\end{array}$ & $\begin{array}{c}\text { VR- } \\
\text { simulation }\end{array}$ & $\begin{array}{l}\text { Phantom } \\
\text { model }\end{array}$ & $\begin{array}{l}\text { Unspecified } \\
\text { developed } \\
\text { system }\end{array}$ & Operators & Time \\
\hline $\begin{array}{l}\text { Zhou et al., } \\
2019 \text { [115] }\end{array}$ & China & $\begin{array}{c}\text { Lumbar } \\
\text { percutaneous } \\
\text { lumbar } \\
\text { discectomy }\end{array}$ & $\begin{array}{c}\text { VR- } \\
\text { simulation }\end{array}$ & $\begin{array}{l}\text { Phantom } \\
\text { model }\end{array}$ & $\begin{array}{l}\text { Unspecified } \\
\text { developed } \\
\text { system }\end{array}$ & Operators & Time \\
\hline $\begin{array}{c}\text { Moult et al., } \\
2013 \text { [116] }\end{array}$ & Canada & $\begin{array}{l}\text { Lumbar facet } \\
\text { joint injection }\end{array}$ & $\begin{array}{c}\text { VR- } \\
\text { simulation }\end{array}$ & $\begin{array}{c}\text { Phantom } \\
\text { model }\end{array}$ & $\begin{array}{l}\text { Perk Tutor, } \\
\text { SonixTouch US } \\
\text { system with } \\
\text { SonixGPS }\end{array}$ & $\begin{array}{l}\text { Medical } \\
\text { students }\end{array}$ & $\begin{array}{l}\text { Accuracy, } \\
\text { Time }\end{array}$ \\
\hline $\begin{array}{c}\text { Moore } \\
\text { et al., 2009 } \\
{[117]}\end{array}$ & Canada & $\begin{array}{l}\text { Lumbar facet } \\
\text { joint injection }\end{array}$ & $\begin{array}{c}\text { VR- } \\
\text { simulation, } \\
\text { AR-guide }\end{array}$ & $\begin{array}{c}\text { Phantom } \\
\text { model }\end{array}$ & $\begin{array}{l}\text { Unspecified } \\
\text { developed } \\
\text { system }\end{array}$ & Anesthetists & Accuracy \\
\hline $\begin{array}{l}\text { Yeo et al., } \\
2011 \text { [118] }\end{array}$ & Canada & $\begin{array}{l}\text { Lumbar facet } \\
\text { joint injection }\end{array}$ & $\begin{array}{c}\text { VR- } \\
\text { simulation }\end{array}$ & $\begin{array}{c}\text { Phantom } \\
\text { model }\end{array}$ & $\begin{array}{c}\text { Perk Station (The } \\
\text { Perk Lab, } \\
\text { Queen's } \\
\text { University, } \\
\text { Canada) }\end{array}$ & $\begin{array}{l}\text { Medical } \\
\text { students }\end{array}$ & $\begin{array}{l}\text { Accuracy, } \\
\text { Time }\end{array}$ \\
\hline
\end{tabular}

$\mathrm{XR}$, extended reality; VR, virtual reality; AR, augmented reality.

Surgical simulations, which range from 3D computer environments to virtual simulations using HMD, are commonly used for training purposes and to assess competency in surgical skills [2,127]. Advances in XR technology for spinal surgery have recently gained traction in comparison to other surgical specialties. With the increase in MISS, the need for simulators to improve procedural skills and visuospatial awareness is important [76]. XR-technology-based simulation can provide residents and students with more immersive and realistic simulations based on actual surgical procedures, with a variety of sensory feedback, including a high-fidelity haptic system. XR-technology-based simulation not only helps residents develop and master their skills, but also helps maintain the skill levels of senior surgeons.

Surgical simulators using XR technology in orthopedics include arthroscopy simulators for shoulder, knee, and hip joint surgery; fracture fixation simulators; and drill simulators [39,127]. In spine surgery, surgical simulators include pedicle screw insertion, vertebroplasty, transvertebral anterior cervical foraminotomy, posterior cervical laminectomy and foraminotomy, percutaneous transforaminal endoscopic discectomy, lumbar 
puncture, and facet injection [76,77]. Lohre et al. [76] reviewed 38 studies that incorporated XR into MISS and reported that training using VR simulators outperformed traditional training methods in terms of both the knowledge and skills of learners in novice and expert surgeons.

Case-specific 3D holograms can provide young surgeons with a more precise image to understand surgical procedures in comparison to a surgery or anatomy textbook [128] (Figure 2A). Therefore, surgical simulation using case-specific 3D holograms can contribute to shortening the operative time and improving surgical safety.

\subsubsection{Surgical Navigation}

A summary of surgical navigation using hologram with $\mathrm{XR}$ technology in spine surgery is shown in Table 2. XR-technology-based navigation in spine surgery has been reported to contribute to safety and accuracy, reduced operating time, reduced radiation exposure, and improved workload [111,129].

Table 2. A summary of surgical navigation with $\mathrm{XR}$ technology in spine surgery.

\begin{tabular}{|c|c|c|c|c|c|}
\hline Study & Country & Procedure & VR/AR & Simulator & Outcome \\
\hline $\begin{array}{l}\text { Elmi-Terander } \\
\text { et al., } 2019 \text { [90] }\end{array}$ & Sweden & $\begin{array}{l}\text { Lumbar pedicle } \\
\text { screw }\end{array}$ & $\begin{array}{l}\text { VR-simulation, } \\
\text { AR-guide }\end{array}$ & $\begin{array}{c}\text { Unspecified developed } \\
\text { system - the ARSN } \\
\text { system }\end{array}$ & $\begin{array}{l}\text { Accuracy, time, } \\
\text { clinical outcomes }\end{array}$ \\
\hline $\begin{array}{l}\text { Edström et al., } \\
2019 \text { [119] }\end{array}$ & Sweden & $\begin{array}{l}\text { Lumbar pedicle } \\
\text { screw }\end{array}$ & $\begin{array}{l}\text { VR-simulation, } \\
\text { AR-guide }\end{array}$ & $\begin{array}{c}\text { Unspecified developed } \\
\text { system - the ARSN } \\
\text { system }\end{array}$ & $\begin{array}{l}\text { Ratiation exposure, } \\
\text { clinical outcomes }\end{array}$ \\
\hline $\begin{array}{c}\text { Umebayashi } \\
\text { et al., } 2018 \text { [120] }\end{array}$ & Japan & $\begin{array}{c}\text { Cervical } \\
\text { foraminotomy }\end{array}$ & AR-guide & $\begin{array}{c}\text { Medtronic } \\
\text { StealthStation S7 }\end{array}$ & $\begin{array}{c}\text { Feasibility of } \\
\text { intraoperative use }\end{array}$ \\
\hline $\begin{array}{l}\text { Kosterhon et al., } \\
2017 \text { [121] }\end{array}$ & Germany & $\begin{array}{l}\text { Lumbar osteotomy } \\
\text { planning }\end{array}$ & $\begin{array}{l}\mathrm{XR} \text {-volume } \\
\text { rendered spine } \\
\text { with VR } \\
\text { preoperative } \\
\text { planning and AR } \\
\text { intraoperative } \\
\text { workflow }\end{array}$ & $\begin{array}{c}\text { Amira R, FEI } \\
\text { Visualization Sciences } \\
\text { Group, version 5.4.2, } \\
\text { Mérignac Cedex, } \\
\text { France }\end{array}$ & $\begin{array}{c}\text { Feasibility of } \\
\text { intraoperative use, } \\
\text { clinical outcomes }\end{array}$ \\
\hline $\begin{array}{c}\text { Abe et al., } 2013 \\
\text { [122] }\end{array}$ & Japan & $\begin{array}{l}\text { Lumbar } \\
\text { percutaneous } \\
\text { intervention }\end{array}$ & AR-guide & $\begin{array}{l}\text { Unspecified developed } \\
\text { system-Virtual } \\
\text { Protractor with } \\
\text { Augmented Reality } \\
\text { (VIPAR) }\end{array}$ & Accuracy \\
\hline $\begin{array}{l}\text { Wei et al., } 2019 \\
\text { [123] }\end{array}$ & China & $\begin{array}{l}\text { Lumbar } \\
\text { percutaneous } \\
\text { intervention }\end{array}$ & AR-guide & $\begin{array}{l}\text { Baholo, Shanghai } \\
\text { Front Computing } \\
\text { Company, China; } \\
\text { Medivi, Changzhou, } \\
\text { China; Hololens, } \\
\text { Microsoft, USA }\end{array}$ & $\begin{array}{c}\text { Time (ope, } \\
\text { radiation), clinical } \\
\text { outcomes }\end{array}$ \\
\hline $\begin{array}{l}\text { Wu et al., } 2014 \\
\text { [124] }\end{array}$ & China & $\begin{array}{l}\text { Lumbar } \\
\text { percutaneous } \\
\text { intervention }\end{array}$ & AR-guide & $\begin{array}{l}\text { Unspecified developed } \\
\text { system }\end{array}$ & $\begin{array}{l}\text { Accuracy, time } \\
\text { (ope, radiation) }\end{array}$ \\
\hline $\begin{array}{c}\text { Carl et al., } 2019 \\
\text { [125] }\end{array}$ & Germany & $\begin{array}{l}\text { Extra- and intradural } \\
\text { tumor resection } \\
\text { (whole spine) }\end{array}$ & AR-guide & $\begin{array}{l}\text { Unspecified developed } \\
\text { system }\end{array}$ & $\begin{array}{c}\text { Feasibility of } \\
\text { intraoperative use }\end{array}$ \\
\hline $\begin{array}{c}\text { Carl et al., } 2019 \\
\text { [126] }\end{array}$ & Germany & $\begin{array}{l}\text { Extra- and intradural } \\
\text { tumor resection } \\
\text { (whole spine) }\end{array}$ & AR-guide & $\begin{array}{l}\text { Unspecified developed } \\
\text { system }\end{array}$ & $\begin{array}{c}\text { Accuracy, ratiation } \\
\text { exposure }\end{array}$ \\
\hline
\end{tabular}




\subsubsection{Safety and Accuracy}

The accuracy of percutaneous pedicle procedures, including screw placement, biopsy and vertebroplasty, has been the topic of concern that has received the most attention because the wrong approach to a pedicle can lead to nerve and vascular damage. Therefore, safety and accuracy are important parameters not only for skilled doctors but also for less skilled operators in an XR-technology-based navigation system. In fact, XR-technologybased navigation has the potential to better inform and assist surgeons in demanding and challenging operations that require a high degree of precision and accuracy. Regarding the safety and accuracy of XR-technology-based navigation, the Food and Drug Administration (FDA) has laid out strict parameters that these systems must meet for the approval of procedures such as pedicle screw placement in accordance with Standard Practice for Measurement of Positional Accuracy of Computer Assisted Surgical Systems $(<3 \mathrm{~mm}$ screw tip deviation, $<3^{\circ}$ angular deviation) $[7,130]$. Terander et al. [90] showed an overall accuracy of $94.1 \%$ for pedicle screw placement, no severe misplacement, and a mean screw placement time of $5.2 \mathrm{~min}$ in the first prospective cohort study of pedicle screw placement with an XR-technology-based operating room based on a video system with four cameras. Subsequently, Burstorm et al. [131], based on the work of Terander et al., evaluated the feasibility and accuracy of a radiation-free XR-technology-based navigation system on two dead pigs and demonstrated a high degree of accuracy $(1.7 \mathrm{~mm}$ accuracy at the entry point, $2.0 \mathrm{~mm}$ accuracy at the device tip, angular deviation of $<2^{\circ}$, and insertion time of $195 \mathrm{~s}$ ). In the future, it would be desirable to verify the results in cases with narrow cervical or thoracic pedicles, complex spinal deformities, or previous surgery [122]. These studies revealed the great potential of XR technology systems in MISS.

Carl et al. applied XR technology for epidural and intradural tumor resection, reporting high accuracy, with an average registration error of $1 \mathrm{~mm}[125,126]$. Advanced visualization with XR technology, combined with additional views displayed on a screen near the surgical field, demonstrated the importance of 3D perception, including good depth-perception resulting in smooth hand-eye coordination $[125,126]$. The potential for the improvement of accuracy and safety of spine surgery procedures appears to be a significant benefit associated with adopting such technology.

\subsubsection{Reduced Operating Time and Radiation Exposure}

The purpose of research into XR technology in spine surgery, besides accuracy and safety, is to reduce the operating time and avoid unnecessary radiation exposure among patients and operating theater staff. Particular attention should be paid to MISS surgery, which is associated with high radiation exposure [43,44]. Several studies have shown a significant reduction in operative time and radiation exposure when using XR technology in comparison to traditional surgical methods $[68,69,119,122,125,126]$. Theoretically, XRtechnology-based navigation could improve the operative efficiency, especially in complex cases where surgeons are required to shift their attention back and forth between the patient and the fluoroscopy monitor all while directing or advancing an instrument. Since XR technology is still in its infancy and new technologies have a learning curve, further improvements can be expected as more cases are followed over time.

\subsubsection{Workload}

Increased workload due to the learning curve of new technology and visual discomfort and fatigue caused by wearing an HMD for a long time are still problems because XR technology is still in the early stages. Since it is necessary to show that XR technology can also significantly reduce workloads, validated questionnaires to check the workload associated with XR technology have been developed, including the Surgical Task Load Index, System Usability score, and NASA-Task load Index (NASA Human Performance Research Group, 1987). Although these questionnaires have been used to evaluate the workload associated with the use of XR technology in spine surgery [132] and liver surgery [8], the studies have 
not been sufficient. Therefore, assessing the workload with XR technology in spine surgery is a future challenge.

\subsection{Rehabilitation}

The application of VR in medicine is not a new technology that has emerged in the $5 \mathrm{G}$ era; the technology that is applied to medicine can be traced back at least 20 years [16]. In terms of patient care, VR has been used as a distraction to relieve pain, known as "VR Analgesia", which has been shown to have analgesic effects.

XR's novelty and immersive nature have been proven to promote motivation, excitement, and task engagement, making virtual rehabilitation more effective than traditional rehabilitation [133]. VR technology has recently been implemented in various clinical settings, including physical, vocational, cognitive, and psychological rehabilitation [134]. The Biodex Balance System (BBS) is a reliable and objective tool for balance assessment and training [135]. Ibrahim et al. [136] objectively demonstrated the effectiveness of VR rehabilitation using the Biodex Balance System. Task-oriented training and treatment gamification also make rehabilitation enjoyable and motivate patients to carry out repetitive tasks. It has been widely adopted in many medical fields, especially in digital healthcare $[133,134,136]$. Therefore, XR-technology-based devices can improve analgesia, compliance, and the effectiveness of rehabilitation in spine medicine, including rehabilitation.

Investigations of VR-based rehabilitation in orthopedic rehabilitation have been carried out in analgesia and have investigated cervical [137-139], lumbar, shoulder, and knee $[56,140]$ range of motion and motor function improvement. In addition, the XRtechnology-based system has enabled patients to undergo standard rehabilitation at home without having to go to a hospital [141,142]. With the advent of an aging society, the number of patients with spinal diseases has been growing. In many countries, a shortage of human resources-such as physical therapists and caregivers-as well as the cost of home and outpatient care, have caused a mismatch between supply and demand in clinical practice [141]. The application of VR technology to additional processes in the field of rehabilitation may reduce the cost and time burden of rehabilitation for doctors and patients. However, this needs to be verified in the future.

\section{Limitations, Future Directions, and Possibilities}

XR technology in spine medicine is still associated with some limitations and challenges. First, it should be compared to investigate the cost-effectiveness (cost, time, comfort, learning curve, satisfaction, and clinical outcomes) because most studies that include substantial data on efficacy and efficiency have been lacking. In recent years, the quality of introductory XR-technology-based devices has continued to improve and the cost has declined, which may reduce the economic burden. Therefore, it will be important to standardize outcomes and identify key clinical parameters that will further assess the need for, benefits of, and economic relevance of this technology to promote its widespread adoption (e.g., the accuracy of collecting virtual physical findings in medical examinations, the accuracy of pedicle screw placement, and the reduced operating time and radiation exposure of surgical simulation/navigation). While higher costs may be a hindrance to implementation at present, the potential for improved accuracy, shorter operating times, and reduced radiation exposure would overcome the high initial cost of these systems. In Japan, hologram-based navigation for spinal surgery is covered by national medical and health insurance. To foster the widespread use and application of XR technology, the creation of diagnostic holograms should be covered by medical and health insurance, such as in cases where it is difficult to understand the anatomy. Second, XR-technology-based navigation has problems that are specific to early technologies: variation in accuracy, image delay, low image resolution, low brightness and contrast, re-registration and re-calibration, installation costs, adaptation to operating room workflow, and staff training. The biggest problem with 3D holograms is the mismatch between the virtual model and the real world, which needs to be further improved. This may be one of the reasons why 3D holograms, 
although used as guides, are not yet widely used as navigation devices in the surgical field [142]. In addition, the effect of the patient's respiratory movement must be taken into account during thoracic spine surgery [90]. At present, XR operating rooms equipped with radiation-free XR-technology-based navigation systems have the combined benefit of high accuracy with no radiation exposure [90].

Most variation in accuracy and technology-related problems is expected to be resolved with the continued advancement of information technology, such as complex feedback processing with AI and machine learning. Image delays can occur in renderings that require extensive processing; normally, this is handled by compressing the polygonized patient organ model to reduce the processing load. Advances in HMD capabilities have improved the problem of visibility of models in the operating room. On the other hand, HMDs have been associated with side effects, such as nausea, headaches, dizziness, fatigue, and vision problems, as well as concerns about battery life, secure network access, and limited movement due to cords [39]. Validation for workload assessment is required to solve the ergonomic problems of HMD. The use of mobile batteries, simplification of volume rendering of models, and cordless HMDs are some other solutions. The potential for high costs and time-consuming training of staff can be a problem specific to new technologies. There is also a risk that inexperienced users may not be able to deal with system failure during surgery.

Third, especially in the elderly population, there are barriers such as digital literacy and access to telehealth technology. If this issue remains unaddressed, the widespread use of telemedicine services using XR technology may be limited to certain populations. On the other hand, as smart devices and video conferencing become more widespread, we believe that older patients will become more comfortable embracing telemedicine.

Fourth, it is possible that we are not prepared for the ethical challenges (privacy, electronic security, legal implications, etc.) associated with the use of virtual environments [143], especially in the collection of personal information through the web by wearable sensors or an HMD for spine medicine. It is possible that recording and sharing personal data may threaten the privacy of individuals. As clinicians adopt technology for service delivery and practice management, it is necessary to discuss ethical issues that may interfere with the assessment and treatment process, effectiveness, and even safety. Naturally, clinicians need to consider the ethical principles of beneficence (maximizing patient benefit) and nonmaleficence (avoiding harm) when conducting assessments and interventions using virtual reality [143].

Lastly, instead of a systematic review, we applied a narrative review methodology to discuss various technologies, including different perspectives and criticisms. This is because the methodology of the systematic review approach requires a more rigorous focus, which was not compatible with the purpose of this paper. In fact, previous reviews on XR technology in spine medicine have not conducted meta-analyses or adequate systematic reviews due to heterogeneity in the study design, outcome measures, and variability. On the other hand, the lack of a systematic methodology in this review makes it impossible to obtain the highest level of current evidence for conditions and technologies. Another limitation of a narrative review is that it cannot seek out all the relevant literature and cover the scientific literature unbiasedly; instead, it discusses pivotal articles known to the authors [133]. It should also be noted that ongoing research may soon make it obsolete.

\section{Conclusions}

This narrative review discussed factors that have promoted the progression of XR technology in spine surgery, including digital transformation, the COVID-19 pandemic, and MISS. In the field of spine medicine, XR technology has been introduced in areas of education, diagnoses, surgery, and rehabilitation, with remarkable results. Although XR technology in spine medicine still has some limitations and challenges, these can be solved by digital transformation. In the future, the introduction of XR technology to spine medicine will bring about disruptive changes in medical education, clinical diag- 
noses, doctor-patient communication, treatment, and rehabilitation, and promote the rapid development of medicine.

Author Contributions: Conceptualization, T.M., M.U. and K.O.; methodology, T.M.; software, T.M.; validation, T.K., M.T., T.Y. and M.S.; formal analysis, T.M.; investigation, T.M.; resources, T.M.; data curation, T.M.; writing-original draft preparation, T.M.; writing-review and editing T.M., M.S. and H.H.; visualization, T.K. and M.S.; supervision, M.M.; project administration, T.M. All authors have read and agreed to the published version of the manuscript.

Funding: This research received no external funding.

Institutional Review Board Statement: Not applicable.

Informed Consent Statement: Not applicable.

Data Availability Statement: Not applicable.

Conflicts of Interest: Sugimoto have the financial relationships disclose; Board member for Holoeyes Inc.

\section{References}

1. Khor, W.S.; Baker, B.; Amin, K.; Chan, A.; Patel, K.; Wong, J. Augmented and virtual reality in surgery-the digital surgical environment: Applications, limitations and legal pitfalls. Ann. Transl. Med. 2016, 4, 454. [CrossRef]

2. Fiani, B.; De Stefano, F.; Kondilis, A.; Covarrubias, C.; Reier, L.; Sarhadi, K. Virtual Reality in Neurosurgery: “Can You See It?”-A Review of the Current Applications and Future Potential. World Neurosurg. 2020, 141, 291-298. [CrossRef]

3. Guha, D.; Alotaibi, N.M.; Nguyen, N.; Gupta, S.; Mcfaul, C.; Yang, V.X.D. Augmented Reality in Neurosurgery: A Review of Current Concepts and Emerging Applications. Can. J. Neurol. Sci. 2017, 44, 235-245. [CrossRef]

4. Azuma, R.T. A survey of augmented reality. Presence 1997, 6, 355-385. [CrossRef]

5. Condino, S.; Turini, G.; Parchi, P.D.; Viglialoro, R.M.; Piolanti, N.; Gesi, M.; Ferrari, M.; Ferrari, V. How to build a patient-specific hybrid simulator for orthopaedic open surgery: Benefits and limits of mixed-reality using the Microsoft HoloLens. J. Healthc. Eng. 2018, 2018, 5435097. [CrossRef] [PubMed]

6. Tepper, O.M.; Rudy, H.L.; Lefkowitz, A.; Weimer, K.A.; Marks, S.M.; Stern, C.S.; Garfein, E.S. Mixed reality with HoloLens: Where virtual reality meets augmented reality in the operating room. Plast. Reconstr. Surg. 2017, 140, 1066-1070. [CrossRef] [PubMed]

7. Sakai, D.; Joyce, K.; Sugimoto, M.; Horikita, N.; Hiyama, A.; Sato, M.; Devitt, A.; Watanabe, M. Augmented, virtual and mixed reality in spinal surgery: A real-world experience. J. Orthop. Surg. 2020, 28, 2309499020952698. [CrossRef] [PubMed]

8. Saito, Y.; Sugimoto, M.; Imura, S.; Morine, Y.; Ikemoto, T.; Iwahashi, S.; Yamada, S.; Shimada, M. Intraoperative 3D hologram support with mixed reality techniques in liver surgery. Ann. Surg. 2020, 271, e4-e7. [CrossRef] [PubMed]

9. Shiga, T.; Sugimoto, M.; Abe, M.; Nishikimi, R.; Yoneoka, Y.; Inoue, Y.; Yoshimatsu, T.; Kusakabe, M.; Kameyama, T. A study on urological navigation surgery applying mixed reality MR, augmented reality AR, virtual reality VR. Jpn. J. Endourol. 2018, 31, 253-259.

10. Yeung, A.W.K.; Tosevska, A.; Klager, E.; Eibensteiner, F.; Laxar, D.; Stoyanov, J.; Glisic, M.; Zeiner, S.; Kulnik, S.T.; Crutzen, R. Virtual and Augmented Reality Applications in Medicine: Analysis of the Scientific Literature. J. Med. Internet Res. 2021, 23, e25499. [CrossRef]

11. Ahmadpour, N.; Randall, H.; Choksi, H.; Gao, A.; Vaughan, C.; Poronnik, P. Virtual Reality interventions for acute and chronic pain management. Int. J. Biochem. Cell Biol. 2019, 114, 105568. [CrossRef] [PubMed]

12. Spiegel, B.M. Virtual medicine: How virtual reality is easing pain, calming nerves and improving health. Med. J. Aust. 2018, 209, 245-247. [CrossRef] [PubMed]

13. Gupta, A.; Scott, K.; Dukewich, M. Innovative Technology Using Virtual Reality in the Treatment of Pain: Does It Reduce Pain via Distraction, or Is There More to It? Pain Med. 2018, 19, 151-159. [CrossRef]

14. Maldaner, N.; Desai, A.; Gautschi, O.P.; Regli, L.; Ratliff, J.K.; Park, J.; Stienen, M.N. Improving the Patient-Physician Relationship in the Digital Era-Transformation From Subjective Questionnaires Into Objective Real-Time and Patient-Specific Data Reporting Tools. Neurospine 2019, 16, 712-714. [CrossRef]

15. Maldaner, N.; Tomkins-Lane, C.; Desai, A.; Zygourakis, C.C.; Weyerbrock, A.; Gautschi, O.P.; Stienen, M.N. Digital transformation in spine research and outcome assessment. Spine J. 2020, 20, 310-311. [CrossRef]

16. Li, D. 5G and intelligence medicine-how the next generation of wireless technology will reconstruct healthcare? Precis. Clin. Med. 2019, 2, 205-208. [CrossRef] [PubMed]

17. Swiatek, P.R.; Weiner, J.A.; Johnson, D.J.; Louie, P.K.; McCarthy, M.H.; Harada, G.K.; Germscheid, N.; Cheung, J.P.Y.; Neva, M.H.; El-Sharkawi, M.; et al. COVID-19 and the rise of virtual medicine in spine surgery: A worldwide study. Eur. Spine J. 2021, 30, 2133-2142. [CrossRef]

18. Gautschi, O.P.; Stienen, M.N.; Hermann, C.; Cadosch, D.; Fournier, J.Y.; Hildebrandt, G. Web-based audiovisual patient information system-a study of preoperative patient information in a neurosurgical department. Acta Neurochir. 2010, 152, 1337-1341. [CrossRef] 
19. Majumder, S.; Mondal, T.; Deen, M.J. Wearable Sensors for Remote Health Monitoring. Sensors 2017, 17, 130. [CrossRef]

20. Harrington, C.M.; Kavanagh, D.O.; Ballester, G.W.; Ballester, A.W.; Dicker, P.; Traynor, O.; Hill, A.; Tierney, S. 360 Operative Videos: A Randomised Cross-Over Study Evaluating Attentiveness and Information Retention. J. Surg. Educ. 2018, 75, 993-1000. [CrossRef]

21. Hsu, C.W.; Wu, C.C.; Chang, M.C.; Wang, J.H.; Lee, M.H.; Chen, Y.H. Feasibility study of wearable cameras: GoPro Hero7, Panasonic HX-A500 and Patriot F850 glass camera for anal surgery recording. A video demonstration. Tech. Coloproctol. 2019, 23, 595-596. [CrossRef]

22. Vara, A.D.; Wu, J.; Shin, A.Y.; Sobol, G.; Wiater, B. Video Recording With a GoPro in Hand and Upper Extremity Surgery. J. Hand Surg. Am. 2016, 41, e383-e387. [CrossRef] [PubMed]

23. Wilczyński, J.; Karolak, P. Relationship between Electromyographic Frequency of the Erector Spinae and Location, Direction, and Number of Spinal Curvatures in Children with Scoliotic Changes. Risk Manag. Healthc. Policy 2021, 14, 1881-1896. [CrossRef] [PubMed]

24. Orlosky, J.; Kiyokawa, K.; Takemura, H. Virtual and Augmented Reality on the 5G Highway. J. Inf. Process. 2017, 25, 133-141. [CrossRef]

25. Tian, W.; Fan, M.; Zeng, C.; Liu, Y.; He, D.; Zhang, Q. Telerobotic Spinal Surgery Based on 5G Network: The First 12 Cases. Neurospine 2020, 17, 114-120. [CrossRef] [PubMed]

26. Rasouli, J.J.; Shao, J.; Neifert, S.; Gibbs, W.N.; Habboub, G.; Steinmetz, M.P.; Benzel, E.; Mroz, T.E. Artificial intelligence and robotics in spine surgery. Glob. Spine J. 2020, 11, 556-564. [CrossRef]

27. Vo, C.D.; Jiang, B.; Azad, T.D.; Crawford, N.R.; Bydon, A.; Theodore, N. Robotic spine surgery: Current state in minimally invasive surgery. Glob. Spine J. 2020, 10 (Suppl. 2), 34S-40S. [CrossRef] [PubMed]

28. Guze, P.A. Using technology to meet the challenges of medical education. Trans. Am. Clin. Clim. Assoc. 2015, 126, 260-270.

29. Rahman, R.; Wood, M.E.; Qian, L.; Price, C.; Johnson, A.A.; Osgood, G.M. Head-mounted display use in surgery: A systematic review. Surg. Innov. 2020, 27, 88-100. [CrossRef]

30. Rojas-Muñoz, E.; Cabrera, M.E.; Lin, C.; Andersen, D.; Popescu, V.; Anderson, K.; Zarzaur, B.L.; Mullis, B.; Wachs, J.P. The System for Telementoring with Augmented Reality (STAR): A head-mounted display to improve surgical coaching and confidence in remote areas. Surgery 2020, 167, 724-731. [CrossRef]

31. Gasco, J.; Patel, A.; Ortega-Barnett, J.; Branch, D.; Desai, S.; Kuo, Y.F.; Luciano, C.; Rizzi, S.; Kania, P.; Matuyauskas, M. Virtual reality spine surgery simulation: An empirical study of its usefulness. Neurol. Res. 2014, 36, 968-973. [CrossRef]

32. Gottschalk, M.; Yoon, S.T.; Park, D.K.; Rhee, J.M.; Mitchell, P.M. Surgical training using three-dimensional simulation in placement of cervical lateral mass screws: A blinded randomized control trial. Spine J. 2015, 15, 168-175. [CrossRef]

33. Iannessi, A.; Marcy, P.-Y.; Clatz, O.; Bertrand, A.-S.; Sugimoto, M. A review of existing and potential computer user interfaces for modern radiology. Insights Imaging 2018, 9, 599-609. [CrossRef]

34. Pelargos, P.E.; Nagasawa, D.T.; Lagman, C.; Tenn, S.; Demos, J.V.; Lee, S.J.; Bui, T.T.; Barnette, N.E.; Bhatt, N.S.; Ung, N.; et al. Utilizing virtual and augmented reality for educational and clinical enhancements in neurosurgery. J. Clin. Neurosci. 2017, 35, 1-4. Available online: https://www-clinicalkey-com.libproxy.lib.unc.edu/service/content/pdf/watermarked/1-s2.0-S096758681 6303162.pdf?locale=en_US (accessed on 1 December 2021). [CrossRef] [PubMed]

35. Fiani, B.; Jenkins, R.; Siddiqi, I.; Khan, A.; Taylor, A. Socioeconomic Impact of COVID-19 on Spinal Instrumentation Companies in the Era of Decreased Elective Surgery. Cureus 2020, 12, e9776. [CrossRef] [PubMed]

36. Bala, L.; Kinross, J.; Martin, G.; Koizia, L.J.; Kooner, A.S.; Shimshon, G.J.; Hurkxkens, T.J.; Pratt, P.J.; Sam, A.H. A remote access mixed reality teaching ward round. Clin. Teach. 2021, 18, 386-390. [CrossRef]

37. Webster, P. Virtual health care in the era of COVID-19. Lancet 2020, 395, 1180-1181. [CrossRef]

38. Halperin, S.J.; Henderson, M.N.; Prenner, S.; Grauer, J.N. Prevalence of Anxiety and Depression among Medical Students during the COVID-19 Pandemic: A Cross-Sectional Study. J. Med. Educ. Curric. Dev. 2021, 8, 2382120521991150. [CrossRef] [PubMed]

39. McKnight, R.R.; Pean, C.A.; Buck, J.S.; Hwang, J.S.; Hsu, J.R.; Pierrie, S.N. Virtual Reality and Augmented Reality-Translating Surgical Training into Surgical Technique. Curr. Rev. Musculoskelet. Med. 2020, 13, 663-674. [CrossRef]

40. Xu, P.; Wang, H.; Liu, Z.-Y.; Mu, W.-D.; Xu, S.-H.; Wang, L.-B.; Chen, C.; Cavanaugh, J.M. An evaluation of three-dimensional image-guided technologies in percutaneous pelvic and acetabular lag screw placement. J. Surg. Res. 2013, 185, 338-346. [CrossRef]

41. Wong, J.M.-L.; Bewsher, S.; Yew, J.; Bucknill, A.; de Steiger, R. Fluoroscopically assisted computer navigation enables accurate percutaneous screw placement for pelvic and acetabular fracture fixation. Injury 2015, 46, 1064-1068. [CrossRef]

42. Zwingmann, J.; Konrad, G.; Kotter, E.; Sudkamp, N.P.; Oberst, M. Computer-navigated iliosacral screw insertion reduces malposition rate and radiation exposure. Clin. Orthop. Relat. Res. 2009, 467, 1833-1838. [CrossRef] [PubMed]

43. Smith, Z.A.; Sugimoto, K.; Lawton, C.D.; Fessler, R.G. Incidence of lumbar spine pedicle breach after percutaneous screw fixation: A radiographic evaluation of 601 screws in 151 patients. J. Spinal Disord. Tech. 2014, 27, 358-363. [CrossRef] [PubMed]

44. Mastrangelo, G.; Fedeli, U.; Fadda, E.; Giovanazzi, A.; Scoizzato, L.; Saia, B. Increased cancer risk among surgeons in an orthopaedic hospital. Occup. Med. 2005, 55, 498-500. [CrossRef]

45. Sugahara, K.; Koyachi, M.; Koyama, Y.; Sugimoto, M.; Matsunaga, S.; Odaka, K.; Abe, S.; Katakura, A. Mixed reality and three dimensional printed models for resection of maxillary tumor: A case report. Quant. Imaging Med. Surg. 2021, 11, 2187-2194. [CrossRef] 
46. Tirelli, G.; de Groodt, J.; Sia, E.; Belgrano, M.G.; Degrassi, F.; Boscolo-Rizzo, P.; Cova, M.A.; Marcuzzo, A.V. Accuracy of the Anatomage Table in detecting extranodal extension in head and neck cancer: A pilot study. J. Med. Imaging 2021, 8, 014502. [CrossRef]

47. Shen, J.; Parent, S.; Wu, J.; Aubin, C.; Mac-Thiong, J.-M.; Kadoury, S.; Newton, P.; Lenke, L.G.; Lafage, V.; Barchi, S.; et al. Towards a new 3D classification for adolescent idiopathic scoliosis. Spine Deform. 2020, 8, 387-396. [CrossRef]

48. Nault, M.-L.; Beauséjour, M.; Roy-Beaudry, M.; Mac-Thiong, J.-M.; De Guise, J.; Labelle, H.; Parent, S. A Predictive Model of Progression for Adolescent Idiopathic Scoliosis Based on 3D Spine Parameters at First Visit. Spine 2020, 45, 605-611. [CrossRef]

49. Boden, S.D.; Davis, D.O.; Dina, T.S.; Patronas, N.J.; Wiesel, S.W. Abnormal magnetic-resonance scans of the lumbar spine in asymptomatic subjects. A prospective investigation. J. Bone Jt. Surg. Am. 1990, 72, 403-408. [CrossRef]

50. Degenhardt, B.F.; Starks, Z.; Bhatia, S. Reliability of the DIERS Formetric 4D Spine Shape Parameters in Adults without Postural Deformities. BioMed Res. Int. 2020, 2020, 1796247. [CrossRef]

51. Watanabe, K.; Aoki, Y.; Matsumoto, M. An Application of Artificial Intelligence to Diagnostic Imaging of Spine Disease: Estimating Spinal Alignment from Moiré Images. Neurospine 2019, 16, 697-702. [CrossRef]

52. Lee, S.I.; Campion, A.; Huang, A.; Park, E.; Garst, J.H.; Jahanforouz, N.; Espinal, M.; Siero, T.; Pollack, S.; Afridi, M.; et al. Identifying predictors for postoperative clinical outcome in lumbar spinal stenosis patients using smart-shoe technology. $J$. Neuroeng. Rehabil. 2017, 14, 77. [CrossRef] [PubMed]

53. Stienen, M.N.; Gautschi, O.P.; Staartjes, V.; Maldaner, N.; Sosnova, M.; Ho, A.L.; Veeravagu, A.; Desai, A.; Zygourakis, C.C.; Park, J.; et al. Reliability of the 6-minute walking test smartphone application. J. Neurosurg. Spine. 2019, 31, 786-793. [CrossRef]

54. Mobbs, R.J.; Ho, D.; Choy, W.J.; Betteridge, C.; Lin, H. COVID-19 is shifting the adoption of wearable monitoring and telemedicine (WearTel) in the delivery of healthcare: Opinion piece. Ann. Transl. Med. 2020, 8, 1285. [CrossRef] [PubMed]

55. Timpano, F.; Bonanno, L.; Bramanti, A.; Pirrotta, F.; Spadaro, L.; Bramanti, P.; Lanzafame, P. Tele-Health and neurology: What is possible? Neurol. Sci. 2013, 34, 2263-2270. [CrossRef] [PubMed]

56. Lee, S.H.; Yeh, S.C.; Chan, R.C.; Chen, S.; Yang, G.; Zheng, L.R. Motor Ingredients Derived from a Wearable Sensor-Based Virtual Reality System for Frozen Shoulder Rehabilitation. BioMed Res. Int. 2016, 2016, 7075464. [CrossRef]

57. Karol, L.A.; Virostek, D.; Felton, K.; Wheeler, L. Effect of compliance counseling on brace use and success in patients with adolescent idiopathic scoliosis. J. Bone Jt. Surg. Am. 2016, 98, 9-14. [CrossRef] [PubMed]

58. Weinstein, S.L.; Dolan, L.; Wright, J.G.; Dobbs, M.B. Effects of bracing in adolescents with idiopathic scoliosis. N. Engl. J. Med. 2013, 369, 1512-1521. [CrossRef]

59. Lee, J.-M.; Byun, W.; Keill, A.; Dinkel, D.; Seo, Y. Comparison of wearable trackers' ability to estimate sleep. Int. J. Environ. Res. Public Health. 2018, 15, 1265. [CrossRef]

60. Mobbs, R.J.; Katsinas, C.J.; Choy, W.J.; Rooke, K.; Maharaj, M. Objective monitoring of activity and Gait Velocity using wearable accelerometer following lumbar microdiscectomy to detect recurrent disc herniation. J. Spine Surg. 2018, 4, 792-797. [CrossRef] [PubMed]

61. Bizzotto, N.; Sandri, A.; Lavini, F.; Dall'Oca, C.; Regis, D. Video in operating room: GoPro HERO3 camera on surgeon's head to flm operations-A test. Surg. Innov. 2014, 21, 338-340. [CrossRef]

62. Kaneko, H.; Ra, E.; Kawano, K.; Yasukawa, T.; Takayama, K.; Iwase, T.; Terasaki, H. Surgical videos with synchronised vertical 2-split screens recording the surgeons' hand movement. Ophthalmologica 2015, 234, 243-246. [CrossRef]

63. Gibby, J.T.; Swenson, S.A.; Cvetko, S.; Rao, R.; Javan, R. Head-mounted display augmented reality to guide pedicle screw placement utilizing computed tomography. Int. J. Comput. Assist. Radiol. Surg 2019, 14, 525-535. [CrossRef]

64. Liebmann, F.; Roner, S.; von Atzigen, M.; Scaramuzza, D.; Sutter, R.; Snedeker, J.; Farshad, M.; Fürnstahl, P. Pedicle screw navigation using surface digitization on the Microsoft HoloLens. Int. J. Comput. Assist. Radiol. Surg. 2019, 14, 1157-1165. [CrossRef]

65. Urakov, T.M.; Wang, M.Y.; Levi, A.D. Workflow caveats in augmented reality-assisted pedicle instrumentation: Cadaver lab World Neurosurg. 2019, 126, e1449-e1455. [CrossRef]

66. Müller, F.; Roner, S.; Liebmann, F.; Spirig, J.M.; Fürnstahl, P.; Farshad, M. Augmented reality navigation for spinal pedicle screw instrumentation using intraoperative 3D imaging. Spine J. 2020, 20, 621-628. [CrossRef]

67. Evans, H.L.; O'Shea, D.J.; Morris, A.E.; Keys, K.A.; Wright, A.S.; Schaad, D.C.; Terasaki, H. A comparison of Google Glass and traditional video vantage points for bedside procedural skill assessment. Am. J. Surg. 2016, 211, 336-342. [CrossRef]

68. Matsukawa, K.; Yato, Y. Smart glasses display device for fluoroscopically guided minimally invasive spinal instrumentation surgery: A preliminary study. J. Neurosurg. Spine 2021, 34, 150-154. [CrossRef]

69. Hiyama, A.; Katoh, H.; Sakai, D.; Watanabe, M. A New Technique that Combines Navigation-Assisted Lateral Interbody Fusion and Percutaneous Placement of Pedicle Screws in the Lateral Decubitus Position with the Surgeon Using Wearable Smart Glasses: A Small Case Series and Technical Note. World Neurosurg. 2021, 146, 232-239. [CrossRef]

70. Golab, M.R.; Breedon, P.J.; Vloeberghs, M. A wearable headset for monitoring electromyography responses within spinal surgery. Eur. Spine J. 2016, 25, 3214-3219. [CrossRef]

71. Liounakos, J.I.; Urakov, T.; Wang, M.Y. Head-up display assisted endoscopic lumbar discectomy-A technical note. Int. J. Med. Robot. 2020, 16, e2089. [CrossRef] [PubMed]

72. Yan, C.; Wu, T.; Huang, K.; He, J.; Liu, H.; Hong, Y.; Wang, B. The Application of Virtual Reality in Cervical Spinal Surgery: A Review. World Neurosurg. 2021, 145, 108-113. [CrossRef] 
73. Chang, K.V.; Wu, W.T.; Chen, M.C.; Chiu, Y.C.; Han, D.-S.; Chen, C.C. Smartphone Application with Virtual Reality Goggles for the Reliable and Valid Measurement of Active Craniocervical Range of Motion. Diagnostics 2019, 9, 71. [CrossRef]

74. Chytas, D.; Johnson, E.O.; Piagkou, M.; Mazarakis, A.; Babis, G.C.; Chronopoulos, E.; Nikolaou, V.S.; Lazaridis, N.; Natsis, K. The role of augmented reality in Anatomical education: An overview. Ann. Anat. 2020, 229, 151463. [CrossRef]

75. Ghaednia, H.; Fourman, M.S.; Lans, A.; Detels, K.; Dijkstra, H.; Lloyd, S.; Sweeney, A.; Oosterhoff, J.H.; Schwab, J.H. Augmented and virtual reality in spine surgery, current applications and future potentials. Spine J. 2021, 21, 1617-1625. [CrossRef]

76. Lohre, R.; Wang, J.C.; Lewandrowski, K.-U.; Goel, D.P. Virtual reality in spinal endoscopy: A paradigm shift in education to support spine surgeons. J. Spine Surg. 2020, 6 (Suppl. 1), S208-S223. [CrossRef]

77. Pfandler, M.; Lazarovici, M.; Stefan, P.; Wucherer, P.; Weigl, M. Virtual reality-based simulators for spine surgery: A systematic review. Spine J. 2017, 17, 1352-1363. [CrossRef]

78. Yoo, J.S.; Patel, D.S.; Hrynewycz, N.M.; Brundage, T.S.; Singh, K. The utility of virtual reality and augmented reality in spine surgery. Ann. Transl. Med. 2019, 7 (Suppl. 5), S171. [CrossRef] [PubMed]

79. Kaylor, J.; Hooper, V.; Wilson, A.; Burkert, R.; Lyda, M.; Fletcher, K.; Bowers, E. Reliability Testing of Augmented Reality Glasses Technology: Establishing the Evidence Base for Telewound Care. J. Wound Ostomy Cont. Nurs. 2019, 46, 485-490. [CrossRef]

80. Dixon, B.J.; Daly, M.J.; Chan, H.H.L.L.; Vescan, A.; Witterick, I.J.; Irish, J.C. In attentional blindness increased with augmented reality surgical navigation. Am. J. Rhinol. Allergy 2014, 28, 433-437. [CrossRef]

81. Ponce, B.A.; Jennings, J.K.; Clay, T.B.; May, M.B.; Huisingh, C.; Sheppard, E.D. Telementoring: Use of augmented reality in orthopaedic education: AAOS exhibit selection. J. Bone Jt. Surg. Am. 2014, 96, e84. [CrossRef]

82. Haddas, R.; Ju, K.L. Gait alteration in cervical spondylotic myelopathy elucidated by ground reaction forces. Spine 2019, 44, 25-31 [CrossRef]

83. Rao, S.S.; Loeb, A.E.; Amin, R.M.; Golladay, G.J.; Levin, A.S.; Thakkar, S.C. Establishing Telemedicine in an Academic Total Joint Arthroplasty Practice: Needs and Opportunities Highlighted by the COVID-19 Pandemic. Arthroplast. Today 2020, 6, 617-622 [CrossRef]

84. Joda, T.; Gallucci, G.; Wismeijer, D.; Zitzmann, N.U. Augmented and virtual reality in dental medicine: A systematic review. Comput. Biol. Med. 2019, 108, 93-100. [CrossRef]

85. Shafi, K.; Lovecchio, F.; Forston, K.; Wyss, J.; Casey, E.; Press, J.; Creighton, A.; Sandhu, H.; Iyer, S. 2020. The Efficacy of Telehealth for the Treatment of Spinal Disorders: Patient-Reported Experiences during the COVID-19 Pandemic. HSS J. 2020, 16, 17-23. [CrossRef]

86. Iyer, S.; Shafi, K.; Lovecchio, F.; Turner, R.; Albert, T.J.; Kim, H.J.; Press, J.; Katsuura, Y.; Sandhu, H.; Schwab, F.; et al. The Spine Physical Examination Using Telemedicine: Strategies and Best Practices. Glob. Spine J. 2022, 12, 8-14. [CrossRef]

87. Peterson, S.; Kuntz, C.; Roush, J. Use of a modified treatment-based classification system for subgrouping patients with low back pain: Agreement between telerehabilitation and face-to-face assessments. Physiother. Theory Pract. 2019, 35, 1078-1086. [CrossRef]

88. Truter, P.; Russell, T.; Fary, R. The validity of physical therapy assessment of low back pain via telerehabilitation in a clinical setting. Telemed. e-Health 2014, 20, 161-167. [CrossRef]

89. Ha, J.; Parekh, P.; Gamble, D.; Masters, J.; Jun, P.; Hester, T.; Daniels, T.; Halai, M. Opportunities and challenges of using augmented reality and heads-up display in orthopaedic surgery: A narrative review. J. Clin. Orthop. Trauma 2021, 18, 209-215, Erratum in J. Clin. Orthop. Trauma 2021, 20, 101539. [CrossRef]

90. Elmi-Terander, A.; Burström, G.; Nachabe, R.; Skulason, H.; Pedersen, K.; Fagerlund, M.; Ståhl, F.; Charalampidis, A.; Söderman, M.; Holmin, S.; et al. Pedicle Screw Placement Using Augmented Reality Surgical Navigation With Intraoperative 3D Imaging: A First In-Human Prospective Cohort Study. Spine 2019, 44, 517-525. [CrossRef]

91. Hou, Y.; Shi, J.; Lin, Y.; Chen, H.; Yuan, W. Virtual surgery simulation versus traditional approaches in training of residents in cervical pedicle screw placement. Arch. Orthop. Trauma Surg. 2018, 138, 777-782. [CrossRef]

92. Hou, Y.; Lin, Y.; Shi, J.; Chen, H.; Yuan, W. Effectiveness of the Thoracic Pedicle Screw Placement Using the Virtual Surgical Training System: A Cadaver Study. Oper. Neurosurg. 2018, 15, 677-685. [CrossRef]

93. Luciano, C.J.; Banerjee, P.P.; Bellotte, B.; Oh, G.M.; Lemole, M.; Charbel, F.T.; Roitberg, B. Learning retention of thoracic pedicle screw placement using a high-resolution augmented reality simulator with haptic feedback. Neurosurgery 2011, 69, ons14-ons19. [CrossRef]

94. Xiang, L.; Zhou, Y.; Wang, H.; Zhang, H.; Song, G.; Zhao, Y.; Han, J.; Liu, J. Significance of preoperative planning simulator for junior surgeons' training of pedicle screw insertion. J. Spinal Disord. Tech. 2015, 28, E25-E29. [CrossRef]

95. Xin, B.; Chen, G.; Wang, Y.; Bai, G.; Gao, X.; Chu, J.; Xiao, J.; Liu, T. The Efficacy of Immersive Virtual Reality Surgical Simulator Training for Pedicle Screw Placement: A Randomized Double-Blind Controlled Trial. World Neurosurg. 2018, 124, e324-e330. [CrossRef] [PubMed]

96. Chitale, R.; Ghobrial, G.M.; Lobel, D. Simulated Lumbar Minimally Invasive Surgery Educational Model with Didactic and Technical Components. Neurosurgery 2013, 73, 107-110.

97. Ma, L.; Zhao, Z.; Chen, F.; Zhang, B.; Fu, L.; Liao, H. Augmented reality surgical navigation with ultrasound-assisted registration for pedicle screw placement: A pilot study. Int. J. Comput. Assist. Radiol. Surg. 2017, 12, 2205-2215. [CrossRef]

98. Molina, C.A.; Theodore, N.; Ahmed, A.K.; Westbroek, E.M.; Mirovsky, Y.; Harel, R.; Orru', E.; Khan, M.; Witham, T.; Sciubba, D.M. Augmented reality-assisted pedicle screw insertion: A cadaveric proof-of-concept study. J. Neurosurg. Spine 2019, 31, 139-146. [CrossRef] 
99. Molina, C.A.; Phillips, F.M.; Colman, M.W.; Ray, W.Z.; Khan, M.; Orru', E.; Poelstra, K.; Khoo, L. A cadaveric precision and accuracy analysis of augmented reality-mediated percutaneous pedicle implant insertion. J. Neurosurg. Spine 2021, 34, 316-324. [CrossRef] [PubMed]

100. Mostafa, A.E.; Ryu, W.H.A.; Chan, S.; Takashima, K.; Kopp, G.; Costa, M.; Scharlin, E. Designing NeuroSimVR: A Stereoscopic Virtual Reality Spine Surgery Simulator. 2017. Available online: https:/ / prism.ucalgary.ca/handle/1880/52230 (accessed on 1 November 2017).

101. Rambani, R.; Ward, J.; Viant, W. Desktop-Based Computer-Assisted Orthopedic Training System for Spinal Surgery. J. Surg. Educ. 2014, 71, 805-809. [CrossRef]

102. Fritz, J.; U-Thainual, P.; Ungi, T.; Flammang, A.J.; McCarthy, E.F.; Fichtinger, G.; Iordachita, I.I.; Carrino, J.A. Augmented Reality Visualization Using Image Overlay Technology for MR-Guided Interventions. Investig. Radiol. 2013, 48, 464-470. [CrossRef]

103. U-Thainual, P.; Fritz, J.; Moonjaita, C.; Ungi, T.; Flammang, A.; Carrino, J.A.; Fichtinger, G.; Iordachita, I. MR image overlay guidance: System evaluation for preclinical use. Int. J. Comput. Assist. Radiol. Surg. 2013, 8, 365-378. [CrossRef]

104. Hummel, F.; Gerloff, C.; Handels, H.; Färber, M. Virtual reality simulator for the training of lumbar punctures. Methods Inf. Med. 2009, 48, 493-501. [CrossRef]

105. Deib, G.; Johnson, A.; Unberath, M.; Yu, K.; Andress, S.; Qian, L.; Osgood, G.; Navab, N.; Hui, F.; Gailloud, P. Image guided percutaneous spine procedures using an optical see-through head mounted display: Proof of concept and rationale. J. NeuroInterv. Surg. 2018, 10, 1187-1191. [CrossRef]

106. Koch, A.; Pfandler, M.; Stefan, P.; Wucherer, P.; Lazarovici, M.; Navab, N.; Stumpf, U.; Schmidmaier, R.; Glaser, J.; Weigl, M. Say, What Is on Your Mind? Surgeons' Evaluations of Realism and Usability of a Virtual Reality Vertebroplasty Simulator. Surg. Innov. 2019, 26, 234-243. [CrossRef]

107. Weigl, M.; Stefan, P.; Abhari, K.; Wucherer, P.; Fallavollita, P.; Lazarovici, M.; Weidert, S.; Euler, E.; Catchpole, K. Intra-operative disruptions, surgeon's mental workload, and technical performance in a full-scale simulated procedure. Surg. Endosc. 2016, 30, 559-566. [CrossRef]

108. Wucherer, P.; Stefan, P.; Weidert, S.; Fallavollita, P.; Navab, N. Task and crisis analysis during surgical training. Int. J. Comput. Assist. Radiol. Surg. 2014, 9, 785-794. [CrossRef]

109. Wucherer, P.; Stefan, P.; Abhari, K.; Fallavollita, P.; Weigl, M.; Lazarovici, M.; Winkler, A.; Weidert, S.; Peters, T.M.; De Ribaupierre, S.; et al. Vertebroplasty Performance on Simulator for 19 Surgeons Using Hierarchical Task Analysis. IEEE Trans. Med. Imaging 2015, 34, 1730-1737. [CrossRef]

110. Dennler, C.; Safa, N.A.; Bauer, D.E.; Wanivenhaus, F.; Liebmann, F.; Götschi, T.; Farshad, M. Augmented Reality Navigated Sacral-Alar-Iliac Screw Insertion. Int. J. Spine Surg. 2021, 15, 161-168. [CrossRef]

111. Jeong, S.T.; Park, Y.S.; Jung, G.H. Computational simulation of sacral-alar-iliac (S2AI) screw fixation of pelvis and implications for fluoroscopic procedure: A cadaver study. J. Orthop. Surg. 2019, 27, 2309499019836246. [CrossRef]

112. Wang, H.; Wang, F.; Leong, A.P.Y.; Xu, L.; Chen, X.; Wang, Q. Precision insertion of percutaneous sacroiliac screws using a novel augmented reality-based navigation system: A pilot study. Int. Orthop. 2016, 40, 1941-1947. [CrossRef] [PubMed]

113. Bisson, M.; Cheriet, F.; Parent, S. 3D visualization tool for minimally invasive discectomy assistance. Stud. Health Technol. Inform. 2010, 158, 55-60.

114. Hu, Z.; Li, X.; Cui, J.; He, X.; Li, C.; Han, Y.; Pan, J.; Yang, M.; Tan, J.; Li, L. Significance of preoperative planning software for puncture and channel establishment in percutaneous endoscopic lumbar DISCECTOMY: A study of 40 cases. Int. J. Surg. 2017, 41, 97-103. [CrossRef] [PubMed]

115. Zhou, Z.; Hu, S.; Zhao, Y.-Z.; Zhu, Y.J.; Wang, C.F.; Gu, X.; Fan, G.X.; He, S.S. Feasibility of Virtual Reality Combined with Isocentric Navigation in Transforaminal Percutaneous Endoscopic Discectomy: A Cadaver Study. Orthop. Surg. 2019, 11, 493-499. [CrossRef]

116. Moult, E.; Ungi, T.; Welch, M.; Lu, J.; McGraw, R.C.; Fichtinger, G. Ultrasound-guided facet joint injection training using Perk Tutor. Int. J. Comput. Assist. Radiol. Surg. 2013, 8, 831-836. [CrossRef]

117. Moore, J.; Clarke, C.; Bainbridge, D.; Wedlake, C.; Wiles, A.; Pace, D.; Peters, T. Image guidance for spinal facet injections using tracked ultrasound. Med. Image Comput. Comput. Assist. Interv. 2009, 12 Pt 1, 516-523. [CrossRef]

118. Yeo, C.T.; Ungi, T.; U-Thainual, P.; Lasso, A.; McGraw, R.C.; Fichtinger, G. The effect of augmented reality training on percutaneous needle placement in spinal facet joint injections. IEEE Trans. Biomed. Eng. 2011, 58, 2031-2037. [CrossRef]

119. Edström, E.; Burström, G.; Omar, A.; Nachabe, R.; Söderman, M.; Persson, O.; Gerdhem, P.; Elmi-Terander, A. Augmented reality surgical navigation in spine surgery to minimize staff radiation exposure. Spine 2020, 45, E45-E53. [CrossRef]

120. Umebayashi, D.; Yamamoto, Y.; Nakajima, Y.; Fukaya, N.; Hara, M. Augmented Reality Visualization-guided Microscopic Spine Surgery: Transvertebral Anterior Cervical Foraminotomy and Posterior Foraminotomy. JAAOS Glob. Res. Rev. 2018, 2, e008. [CrossRef]

121. Kosterhon, M.; Gutenberg, A.; Kantelhardt, S.R.; Archavlis, E.; Giese, A. Navigation and Image Injection for Control of Bone Removal and Osteotomy Planes in Spine Surgery. Oper. Neurosurg. 2017, 13, 297-304. [CrossRef]

122. Abe, Y.; Sato, S.; Kato, K.; Hyakumachi, T.; Yanagibashi, Y.; Ito, M.; Abumi, K. A novel 3D guidance system using augmented reality for percutaneous vertebroplasty: Technical note. J. Neurosurg. Spine 2013, 19, 492-501. [CrossRef]

123. Wei, P.; Yao, Q.; Xu, Y.; Zhang, H.; Gu, Y.; Wang, L. Percutaneous kyphoplasty assisted with/without mixed reality technology in treatment of OVCF with IVC: A prospective study. J. Orthop. Surg. Res. 2019, 14, 255. [CrossRef] [PubMed] 
124. Wu, J.R.; Wang, M.L.; Liu, K.C.; Hu, M.H.; Lee, P.Y. Real-time advanced spinal surgery via visible patient model and augmented reality system. Comput. Methods Progr. Biomed. 2014, 113, 869-881. [CrossRef]

125. Carl, B.; Bopp, M.; Saß, B.; Voellger, B.; Nimsky, C. Implementation of augmented reality support in spine surgery. Eur. Spine J. 2019, 28, 1697-1711. [CrossRef]

126. Carl, B.; Bopp, M.; Saß, B.; Pojskic, M.; Gjorgjevski, M.; Voellger, B.; Nimsky, C. Reliable navigation registration in cranial and spine surgery based on intraoperative computed tomography. Neurosurg. Focus 2019, 47, E11. [CrossRef]

127. Bartlett, J.D.; Lawrence, J.E.; Stewart, M.E.; Nakano, N.; Khanduja, V. Does virtual reality simulation have a role in training trauma and orthopaedic surgeons? Bone Jt. J. 2018, 100-B, 559-565. [CrossRef]

128. Mitani, S.; Sato, E.; Kawaguchi, N.; Sawada, S.; Sakamoto, K.; Kitani, T.; Sanada, T.; Yamada, H.; Hato, N. Case-specific threedimensional hologram with a mixed reality technique for tumor resection in otolaryngology. Laryngoscope 2021, 6, $432-437$. [CrossRef]

129. Min, W.K.; Na, S.B.; Jang, J.A. Accuracy of thoracic pedicle screw placement using freehand technique and triggered EMG in adolescent idiopathic scoliosis: Is it different between concave and convex side? J. Orthop. Surg. 2018, 26, 2309499018784975. [CrossRef]

130. ASTM F2554-10; Standard Practice for Measurement of Positional Accuracy of Computer Assisted Surgical Systems. ASTM International: West Conshohocken, PA, USA, 2010. Available online: www.astm.org(accessed on 1 December 2021).

131. Burström, G.; Nachabe, R.; Persson, O.; Edström, E.; Terander, A.E. Augmented and Virtual Reality Instrument Tracking for Minimally Invasive Spine Surgery: A Feasibility and Accuracy Study. Spine 2019, 44, 1097-1104. [CrossRef]

132. Cofano, F.; Di Perna, G.; Bozzaro, M.; Longo, A.; Marengo, N.; Zenga, F.; Zullo, N.; Cavalieri, M.; Damiani, L.; Boges, D.J.; et al Augmented Reality in Medical Practice: From Spine Surgery to Remote Assistance. Front. Surg. 2021, 8, 657901. [CrossRef]

133. Nizamis, K.; Athanasiou, A.; Almpani, S.; Dimitrousis, C.; Astaras, A. Converging Robotic Technologies in Targeted Neural Rehabilitation: A Review of Emerging Solutions and Challenges. Sensors 2021, 21, 2084. [CrossRef] [PubMed]

134. Omon, K.; Hara, M.; Ishikawa, H. Virtual Reality-guided, Dual-task, Body Trunk Balance Training in the Sitting Position Improved Walking Ability without Improving Leg Strength. Prog. Rehabil. Med. 2019, 4, 20190011. [CrossRef]

135. Wilczyński, J.; Kabała, M.; Paprocki, M.; Rychter, P.; Wilczyński, I. Evaluation of postural stability of people with Parkinson's disease with Biodex Balance System device. J. Educ. Health Sport 2016, 6, 365-376.

136. Ibrahim, M.; Mattar, A.G.; Elhafez, S.M. Efficacy of virtual reality-based balance training versus the Biodex balance system training on the body balance of adults. J. Phys. Ther. Sci. 2016, 28, 20-26. [CrossRef]

137. Sarig Bahat, H.; Takasaki, H.; Chen, X.; Bet-Or, Y.; Treleaven, J. Cervical kinematic training with and without interactive VR training for chronic neck pain-A randomized clinical trial. Man Ther. 2015, 20, 68-78. [CrossRef]

138. Sarig Bahat, H.; Sprecher, E.; Sela, I.; Treleaven, J. Neck motion kinematics: An inter-tester reliability study using an interactive neck VR assessment in asymptomatic individuals. Eur. Spine J. 2016, 25, 2139-2148. [CrossRef]

139. Xu, X.; Chen, K.B.; Lin, J.-H.; Radwin, R.G. The accuracy of the Oculus Rift virtual reality head-mounted display during cervical spine mobility measurement. J. Biomech. 2015, 48, 721-724. [CrossRef]

140. Gokeler, A.; Bisschop, M.; Myer, G.D.; Benjaminse, A.; Dijkstra, P.U.; van Keeken, H.; Van Raay, J.J.A.M.; Burgerhof, J.G.M.; Otten, E. Immersive virtual reality improves movement patterns in patients after ACL reconstruction: Implications for enhanced criteria-based return-to-sport rehabilitation. Knee Surg. Sports Traumatol. Arthrosc. 2016, 24, 2280-2286. [CrossRef]

141. Hara, M.; Kitamura, T.; Murakawa, Y.; Shimba, K.; Yamaguchi, S.; Tamaki, M. Safety and Feasibility of Dual-task Rehabilitation Program for Body Trunk Balance Using Virtual Reality and Three-dimensional Tracking Technologies. Prog. Rehabil. Med. 2018, 3, 20180016. [CrossRef]

142. Mitsuno, D.; Ueda, K.; Hirota, Y.; Ogino, M. Effective application of mixed reality device hololens: Simple manual alignment of surgical field and holograms. Plast. Reconstr. Surg. 2019, 143, 647-651. [CrossRef] [PubMed]

143. Parsons, T.D. Ethical Challenges of Using Virtual Environments in the Assessment and Treatment of Psychopathological Disorders. J. Clin. Med. 2021, 10, 378. [CrossRef] [PubMed] 